\title{
DIRECT TRADE IN THE SPECIALTY COFFEE MARKET: CONTRIBUTIONS, LIMITATIONS AND NEW LINES OF RESEARCH
}

Elisa Reis Guimarães ${ }^{1}$, Antônio Carlos dos Santos, Paulo Henrique Montagnana Vicente Leme, Angélica da Silva Azevedo Universidade Federal de Lavras - UFLA, Lavras, MG (Brasil)

\section{ARTICLE DETAILS}

\section{Article history:}

Received: 20 December 2019

Accepted: 25 June 2020

Available online August: 01 th 2020

Double Blind Review System

Scientific Editor

llan Avrichir

\section{Key words}

Relationship Coffees

Fair Trade

Sustainability

Strategy

Specialty Coffee

\begin{abstract}
Study aim: we aimed to outline the direct trade of specialty coffees' global research and adoption, highlighting its contributions, limitations and theoretical and empirical gaps, providing insights for future studies.

Method: integrative systematic review of selected academic materials from the Web of Knowledge, SciELO, Scopus, Science Direct and Scholar Google databases, as well as technical materials from the Specialty Coffee Association and the Perfect Daily Grind portals, which were analyzed using the qualitative and open grid categorical content analysis technique.

Main results: we identified three categories of contributions associated with Direct Trade - "Relationship and Coordination", "Origin and Sustainability" and "Quality and Differentiation" and three categories of its limitations - "Conceptual and Regulatory", "Execution and Monitoring" and "Potential of Transformation and Accessibility". Despite its potential to contribute to the promotion of the sustainability of this market, Direct Trade is not the only solution to the many and complex challenges of the activity. Therefore, it should be adapted to local realities and be carefully adopted, preferably in conjunction with other initiatives aimed at opening different markets and reaching different consumer audiences.

Relevance/originality: this is the first systematic review of the subject, required by the rapid growth of studies in the field, despite its currentness and only recent expansion of the debate.

Theoretical/methodological contributions: we presented a new concept of Direct Trade, subdivided the practice into two perspectives - relational and transactional and elaborated a framework for its realization.
\end{abstract}

\section{INTRODUCTION}

Coffee represents an important source of income and subsistence for approximately 125 million people worldwide, including 25 million coffee farmers, who historically represent the most vulnerable link in the coffee supply chain. This vulnerability is due to dependence on climatic conditions, susceptibility of the product to pests and disease, high price volatility, difficulty in financing the activity or several other factors (Borrella, Mataix \& Carrasco-Gallego, 2015; Folmer et al., 2017).

Given the diversity and complexity of the problems faced by coffee farmers, which directly or indirectly impact the activity of the other actors in this chain, different initiatives have been proposed to promote the sustainable development of coffee farming (Perez et al., 2017). These proposals are constantly supported by the action and partnership between public and private actors as well as nongovernmental and nonprofit organizations, which have transformed this market into a "global laboratory for testing models of equitable and sustainable rural development" (Folmer et al., 2017, p. 24).

Such initiatives include the implementation of the International Coffee Agreements (ICAs), the advent of certifications and the practice of direct trade, which is the focus of this work. However, while the ICAs and certifications are already widely documented in the technical and scientific literature (Akiyama \& Varangis, 1990; Auld, 2010; Bacon, Méndez, Gómez, Stuart \& Flores, 2008; Barham \& Weber, 2012; Clarke, Barnett, Cloke \& Malpass, 2007; Gilbert, 1996; among many others), direct trade remains little explored (Borrella et al., 2015). Its debate usually takes place in events, specialized news portals, blogs and online

\footnotetext{
${ }^{1}$ Contact of the author Email: elisa.rguimaraes@ufla.br
} 
social networks, lacking new theoretical-empirical studies that contribute to its better understanding and greater effectiveness. In addition, the absence both of a third-party certification and a consensual concept, which is commonly misused (Edelmann, Quiñones-Ruiz, \& Penker, 2020; Hernandez-Aguilera et al., 2018; Vicol et al., 2018) hinders this practice's study and its transformative potential.

Thus, through a systematic integrative review, the objective of this study is to provide an overview of the global research regarding the adoption of the direct trade of specialty coffees, highlighting its contributions, limitations and gaps as well as providing insights for future studies and assessing the alignment between the academic and technical perspectives on the subject. As recommended by Adams, Smart, \& Huff (2017) in novel fields, we selected both academic and technical materials, seeking a detailed and practical comprehension on the subject that can support the establishment of higher-order theoretical constructs for its analysis, and validate or challenge academic sources' findings and assumptions.

In this way, we hope to establish a general concept on Direct Trade that recognizes its most important theoretical and practical dimensions and its different steps and modes of adoption, guiding future empirical studies on the topic and supporting Direct Trade's practitioners decision making.

The next sections will present the origins and motivations of direct trade. The subsequent sections include the methodology, the results and discussions, the conclusions of this research and the references used.

\section{DIRECT TRADE AND SPECIALTY COFFEES}

Defined by Norwegian Erna Knutsen in 1974, the term 'specialty coffee' designates coffees from special geographic microclimates that produce beans with unique sensory profiles (Guimarães, Castro Júnior, \& Andrade, 2016; Hotvedt, 2012). With the recent growth of these coffees on the international market, direct supply initiatives that assist in the promotion of coffee bean traceability and quality were developed, providing management solutions to some sustainability challenges (Panhuysen \& Pierrot, 2018; Pulido, 2017), provided that they are properly performed.
Suppliers of fresh beans, roasters or retailers thus tend to develop their own internal sustainable purchasing programs, sometimes in partnership with organizations that adopt voluntary sustainability standards (Panhuysen \& Pierrot, 2018). Such direct trade programs often share some of the principles of fair trade, such as shortening the supply chain, fair remuneration for coffee farmers and incentives for good productive practices, but go far beyond that in its implementation (Edelmann, Quiñones-Ruiz \& Penker, 2020; Lautz, 2011; Leeson, 2013). Moreover, they consider the quality normally achieved by certified coffees to be unsatisfactory (MacGregor, Ramasar \& Nicholas, 2017; Olsen, 2012), considering their active involvement with coffee farmers essential for obtaining beans of exceptional quality (Lannigan, 2020; Vicol, Neilson, Hartatri, \& Cooper, 2018). For these reasons, these programs are perceived by different agents as an evolution of the initiatives adopted until then, or the "new fair trade" (Carvalho, 2016; Latta, 2014; Liu, 2016).

The emergence of direct trade results from the frustration with the supply consistency of the market for exceptional quality coffees, hindered by its limited availability and difficulty of access to farmers due to the supply chain's lack of transparency and traceability (Watts, 2013). Therefore, there was a need for coordination among agents, achieved through joint work and information sharing (Boaventura, Abdalla, Araújo, \& Arakelian, 2018; Bode \& Piechaczek, 2007). Thus, the roasters limited their interactions with intermediaries in coffee bean acquisition but continued to include those agents in the supply chain when legitimate and necessary (Hotvedt, 2012; Vicol et al., 2018). The business view of the companies involved in direct trade also included a strong desire to address aspects of sustainability considered intrinsically linked to coffee production (Borrella et al., 2015; MacGregor et al., 2017; Watts, 2013).

This practice gained popularity in the mid-1990s; however, the term 'direct trade', coined by Geoff Watts, only dates back to the year 2006 (Hotvedt, 2012). Since no third-party certifier regulates the practice, it has no single definition or a set of preestablished rules (Hernandez-Aguilera et al., 2018; Olsen, 2012; Vicol et al., 2018). The common traits among models are usually related to product quality, environmental, economical, and social concerns and frequent communication between farmers and green coffee buyers, involving constant visits of the latter to 
the farm (Gerard, Lopez, \& McCright, 2019; MacGregor et al., 2017; Olsen, 2012).

The lack of third-party certification also results in the existence of different forms of direct trade adoption, which usually reflects in different levels of roasters' involvement (MacGregor et al., 2017; Olsen, 2012). Thus, there is concern that the proposed benefits are not effectively achieved, which is exacerbated by the lack of transparency of some of these initiatives (Edelmann et al., 2020; Gerard et al., 2019; Panhuysen \& Pierrot, 2018).

Despite its transformative potential, direct trade still lacks studies on its real benefits, limitations and practical implementation as well as on its constitution and organization as a new market configuration. The academic knowledge on the topic is still scarce, but we highlight the works of Borrella et al. (2015), Edelmann et al. (2020), Hernandez-Aguilera et al. (2018) and MacGregor et al. (2017), which have been guiding important research and knowledge construction on the practice, whether it is called Direct Trade, Relationship Coffee or others.

This article, therefore, aims to fill this gap through the methodological procedures presented in the next section.

\section{METHODOLOGY}

This qualitative and exploratory study consists on a systematic integrative review i.e., a rigorous analysis using systematic and explicit methods for the synthesis of previous theoretical and empirical literature, to provide a broad understanding of a specific phenomenon and promote knowledge generation (Botelho, Cunha \& Macedo, 2011).

Direct trade was selected as the object of study for its growing relevance in the specialty coffee market and its differentiated proposal for the promotion of environmental, social and economic development of this sector. This study sought to present a qualitative review of academic research on direct trade, providing an overview of its worldwide research and adoption, highlighting its contributions, limitations and theoretical and empirical gaps, and providing insights for future studies. In addition, it sought to determine the alignment between the academic and technical perspectives on the subject. This is the first systematic review of the subject, required by the rapid growth of studies in the field, despite its currentness and only recent expansion of the debate.
For this reason, both 'white' and 'grey' literature are addressed in this study, the later understood as "the diverse and heterogeneous body of material available outside, and not subject to, traditional academic peer-review processes" (Adams, Smart, \& Huff, 2017, p. 433). Similar approaches have been adopted on several other management and organizational studies published in high-impact and prestige journals (see Adams, Jeanrenaud, Bessant, Denyer, \& Overy, 2016; Cluley, 2018; Dorval, Jobin, \& Benomar, 2019; Esmaeili, \& Hashemi G., 2019; Nandonde, \& Kuada, 2016).

This strategy is specially recommended in emergent fields where academic knowledge alone may "fail to provide a sufficiently rich, detailed and practical understanding of complex interventions" (Adams, Smart, \& Huff, 2017, p. 446) and to extend the scope of findings by "incorporating relevant contemporary material in dynamic and applied topic areas where scholarship lags" (p. 434). In an academic perspective and in novel fields, it may also help building higher-order theoretical constructs for the subject's analysis, and validate or challenge academic sources' findings and assumptions (Adams, Smart, \& Huff, 2017).

Grey literature should be used as complementary evidence, 'synthesizing' diverse bodies of evidence and, thus, contributing to discourse and practice by incorporating supplementary narratives. In other words, grey literature may bring non-academic users/stakeholders to the debate, enhancing the comprehension of applied contexts and the results' practical/policy impact (Adams, Smart, \& Huff, 2017) and reconnecting systematic reviews to its original practice-oriented purpose (Tranfield, Denyer, \& Smart, 2003).

Despite its benefits, the use and combination of white and grey literature should be cautious and judicious. It demands alternative and study-specific quality appraisal criteria, preferentially based on "outlet control (the extent to which content is produced, moderated or edited in conformance with explicit and transparent knowledge creation criteria) and source expertise (the extent to which the authority of the producer of content can be determined)" (Adams, Smart, \& Huff, 2017, p. 436). Thus, we used different material searching processes, described below, to select white and grey literature.

Due to their relevance for research in the Social Sciences, we used the index databases Web of 
Science, Scopus, SciELO, Science Direct and Google Scholar for locating and selecting 'white' academic materials, in this case, peer-reviewed scientific papers published in academic journals. We also used these databases to select grey materials that include masters' or doctoral dissertations and theses. Despite being academic and usually peer-reviewed, such researches constitute 'work in progress' and lack double-blind reviews. However, due to the paucity of published 'white' literature about Direct Trade, their inclusion aimed at identifying trends that might influence this area's future state of the art.

The sources for technical materials included the Specialty Coffee Association (SCA) website and the Perfect Daily Grind website - specialized in the publication of news and technical information about specialty coffees by professionals around the world , selected by their reputation and authority in the specialty coffee market. In addition, we also used the mentioned index databases for the selection of books and chapters related to the topic. As emphasized by Kallio, Pietilä, Johnson and Kangasniemi (2016, p. 6), "in the case of sparse or fragmented knowledge in the literature", which is the case of the topic in question, "empirical knowledge could be used to complement and deepen the theoretical background", helping to understand the phenomenon under study. Therefore, this study sought to achieve an in-depth theoretical-empirical understanding of direct trade.

This study comprises published materials - in English and Portuguese - until May 2020, selected using the search terms shown in Table 1, both for academic and technical materials. Although the term "Direct Trade" emerged in 2006, we decided not to use a time filter. This is because, in practice, Direct Trade has been observed since the early 1990s, and has been called in different ways ever since.

Table 1 Search terms used in research.

\begin{tabular}{l}
\hline Search terms \\
\hline "Comércio Direto" AND "Café Especial*" \\
\hline "Crop to Cup" AND "Specialty Coffee*" \\
\hline "Direct Origin" AND "Specialty Coffee*" \\
\hline "Direct Procurement Model" AND "Specialty Coffee*" \\
\hline "Direct Relationship*" AND "Specialty Coffee*" \\
\hline "Direct Specialty Trade" AND "Specialty Coffee*" \\
\hline "Direct Trade" AND "Specialty Coffee*" \\
\hline "Farm Direct Sourcing" AND "Specialty Coffee*" \\
\hline "Farm Friendly" AND "Specialty Coffee*" \\
\hline "Origin Trip*" AND "Specialty Coffee*" \\
\hline "Relationship Coffee*" AND "Specialty Coffee*" \\
\hline "Relationship Based Trade" AND "Specialty Coffee*" \\
\hline "Working Relationship*" AND "Specialty Coffee*" \\
* Use of the term and its variation in the plural
\end{tabular}

The searches, conducted between June 01 and 02, 2020, resulted in the selection of 56 academic and 39 technical materials after using the following exclusion criteria (Table 2). Due to its inherent characteristics, the selection of technical materials followed only the Exclusion Criterion III. 
Table 2 Academic materials exclusion criteria

\begin{tabular}{|l|l|}
\hline $\begin{array}{l}\text { Exclusion Criterion I: only researches related to specialty coffees' } \\
\text { production, industrialization, commercialization, sustainability, quality, } \\
\text { and consumption were selected and sent to the reference manager }\end{array}$ & $\begin{array}{l}\text { Web of Science } \\
\text { Scopus } \\
\text { SciELO Citation Index } \\
\text { Science Direct } \\
\text { Scholar Google } \\
\text { Total }\end{array}$ \\
07 \\
00 \\
28 \\
305 \\
345 \\
\hline $\begin{array}{l}\text { Exclusion Criterion II: researches that were not fully available, were not } \\
\text { subject to peer review, were duplicate or were later published in } \\
\text { journals were removed from the reference manager }\end{array}$
\end{tabular}

The 95 selected materials were coded according to their category (Appendix $A$ and $B$ ) and were subject to the content analysis technique for its content coding and analysis. A qualitative and semantic (Bastos, de Oliveira, Souza, Santos, \& do Lago, 2019) approach was used, not centered on the frequency of citations of a term in the text but rather on its presence or not in the selected material.

The content analysis' operationalization followed the three stages proposed by Cavalcante, Calixto, and Pinheiro (2014): i) pre-analysis; ii) material exploration/encoding; and iii) data processing/interpretation. In the pre-analysis stage, we carried out a floating reading of all the selected material to understand, in a comprehensive manner, its main ideas and their general meanings.

In the next stage and through a careful reading of the entire corpus, we proceeded to the thematic analysis (Campos, 2004) of the material, adopting as basic units of analysis sentences, phrases or paragraphs associated with the Direct Trade of specialty coffees. After a recursive process, they were synthetized into our 'featured topics' (Tables 4 and 5).

Finally, in the data processing/interpretation stage, those 'featured topics' were organized into non-aprioristic categories after identification of their shared characteristics (Campos, 2004; Caregnato \& Mutti, 2006), an option justified by the recent popularity of the topic and the lack of pre-established categories in previous studies.

\section{RESULTS AND DISCUSSION}

Our searches resulted in the selection of 95 materials for analysis: 56 academic and 39 technical works. Table 3 presents their characterization and contribution to the sample.

Table 3 Characterization of selected materials.

\begin{tabular}{lcc}
\hline Type & Quantity & Percentage \\
\hline Academic & & \\
\hline Monograph/Dissertation /Thesis & 31 & $32,6 \%$ \\
\hline Scientific article published in journal or event & 25 & $26,3 \%$ \\
\hline Subtotal & 56 & $58,9 \%$ \\
\hline Technical & 29 & $30,5 \%$ \\
\hline Opinion article & 10 & $10,5 \% \%$ \\
\hline Book or book chapter & 39 & $41,1 \%$ \\
\hline Subtotal & 95 & $100 \%$ \\
\hline Total & & \\
\hline
\end{tabular}

There is a predominance of academic papers produced as a requirement for obtaining degrees in higher education institutions, which account for $32.6 \%$ of the selected materials, followed by opinion 
articles and scientific papers. However, such percentages may not reflect the relative global share of these publications due to possible biases in determining the consulted sources. Recent and growing interest in the subject is evident, first mentioned in the selected materials in 2008 but which received increased attention in the last years, as shown in Figure 1.

Figure 1 - Total published materials per year

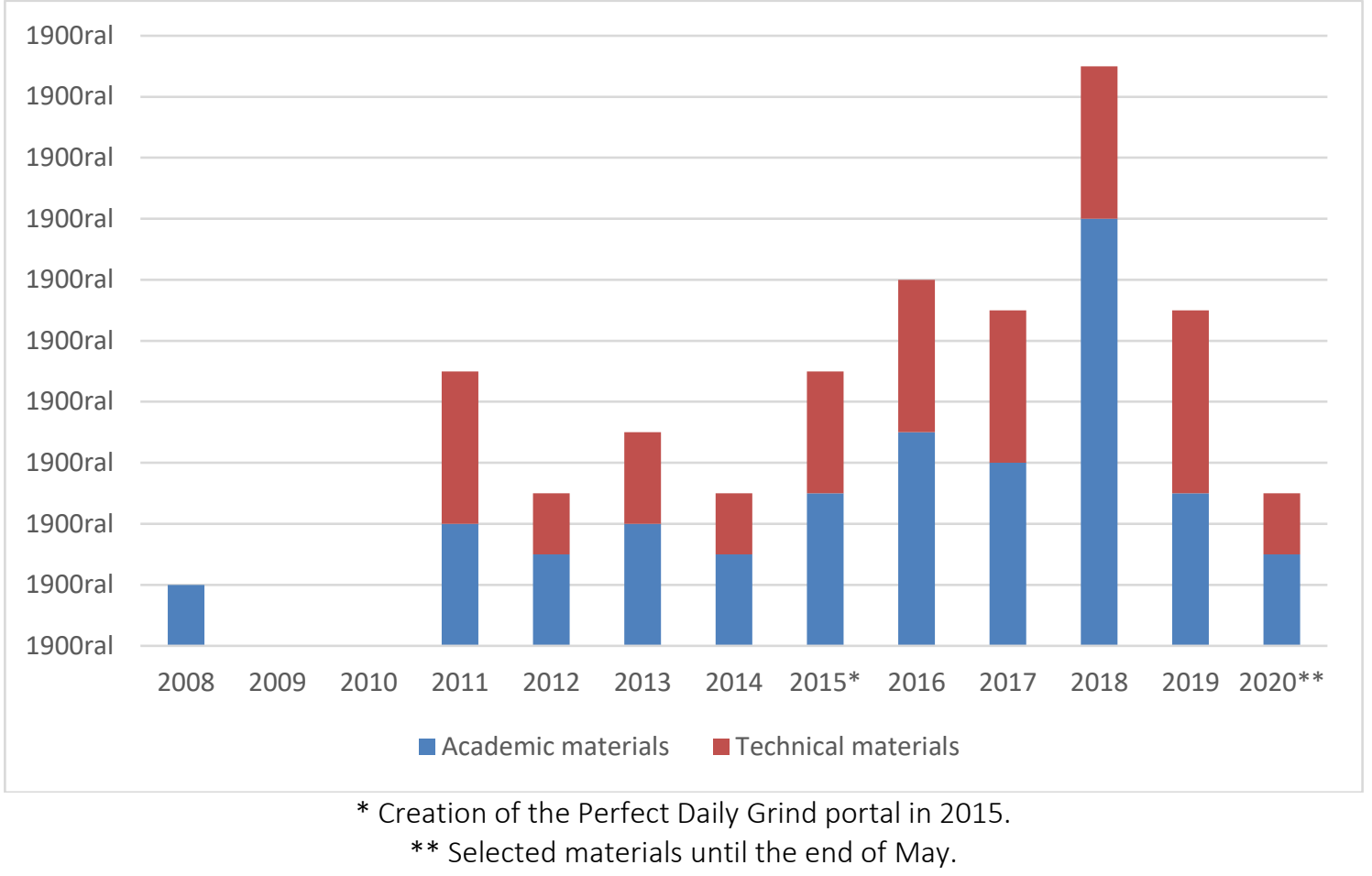

Despite this, only 41 of the selected materials (43.1\%) - 25 of them academic and 16 technical works - present direct trade as a central theme (or one of the central themes), indicating that little attention has been given to the theme. There was also a predominance of studies with multiple perspectives, i.e., with more than one category of agents, with a predominance of the combination of the views of coffee farmers and green coffee buyers. Notably, however, there is an absence of studies that can "close the cycle" of the supply chain, i.e., studies that address direct trade from the perspective of all actors involved in this activity, including coffee farmers, roasters/coffee shops and consumers.

\subsection{Potential and contributions of direct trade}

The potential and contributions of direct trade were organized into three categories - "Relationship and Coordination", "Origin and Sustainability" and "Quality and Product Differentiation" (Table 4) established according to the proximity of its subthemes as suggested by Campos (2004) and Caregnato and Mutti (2006). 
Table 4 Categories, featured topics, and references about Direct Trade contributions

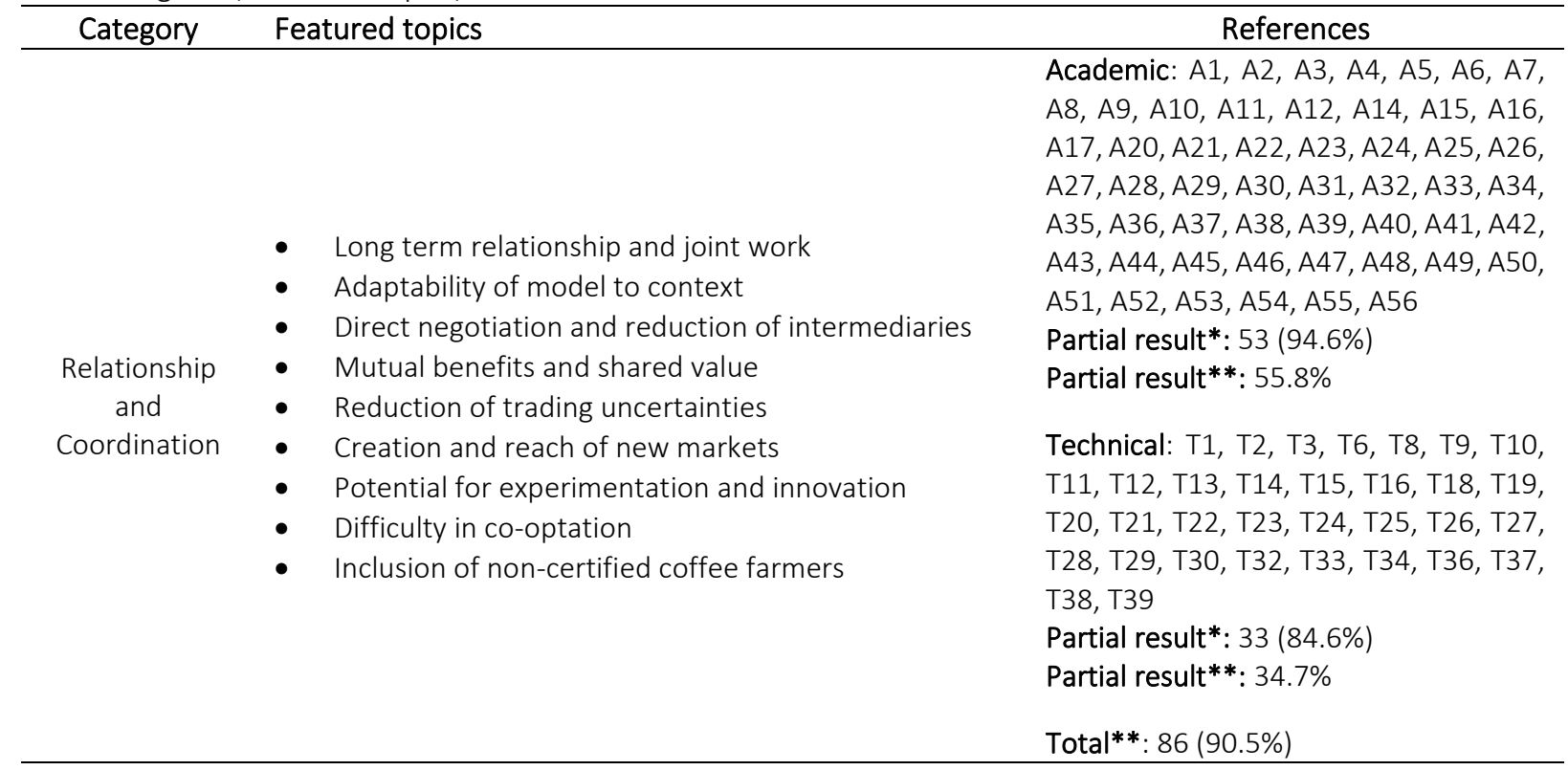

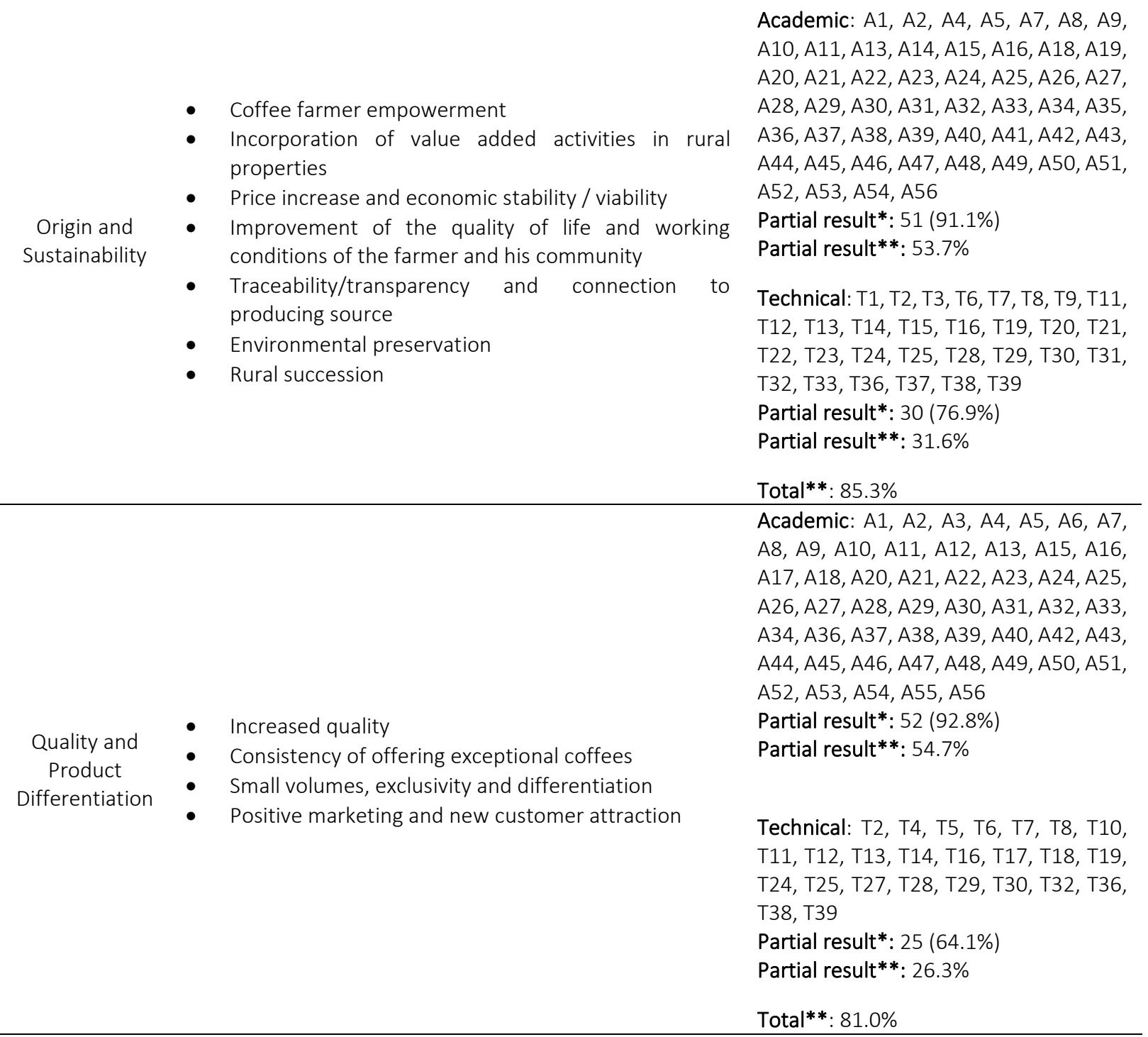

\footnotetext{
* Among the same material category (i.e. academic or technical);
}

** Among total number of selected materials 
The direct and long-term relationship between the agents, based on the principles of trust and transparency (Badiyan-Eyford, 2013; Kolk \& Lenfant, 2016; Olsen, 2012), is at the core of direct trade. Direct trade between green coffee buyers and coffee farmers allows greater appropriation of profits by the later (Leeson, 2013), while the long-term relationship mitigates some of their trading uncertainties, allowing better planning and targeting of their investments (Olsen, 2012).

Through this relationship, supply chain coordination is improved and information asymmetries are reduced (Schroeder, 2015), and it is possible to work together for the sustainability and quality of coffee (Samper, Giovanucci \& Vieira, 2017). As highlighted by Hotvedt (2012), four main factors are responsible for coffee bean quality: environmental patterns, cultivation practices, genotypic variety of the beans, and processing and postharvest methods. This proximity between agents allows buyers to influence these factors and potentiate the experimentation with new harvesting, crop management and postharvest methods, promoting product innovation and, consequently, the creation and access of new markets. It also enables the alignment of product characteristics with the demand of the buyer and customers, generating mutual benefit and shared value among the agents (Leeson, 2013).

However, green coffee buyers should be careful to avoid misleading coffee farmers eager to establish a direct relationship. In this sense, some buyers build a strong relationship with coffee farmers before suggesting changes to production process practices and usually rely on producers to make the appropriate investment decisions (Schroeder, 2015; Strand, 2014).

All this makes direct trade significantly adaptable to the context, not only in terms of production and commercial aspects but also in terms of environmental and socioeconomic issues (Foster, 2011; Hotvedt, 2012; Leeson, 2013; Olsen, 2012). The model considers the local reality, being able to address the specific problems of a region and allowing coffee farmers to adopt only the viable practices relevant to their farm.

For this reason, Intelligentsia, one of the most worldwide renowned specialty coffee roaster, adopted a different pricing system, which is based on the quality of the beans but also considers local production costs and sustainability requirements. Thus, the company commits to pay a minimum price, which is at least $25 \%$ higher than that established by the fair trade certification and which accounts for the necessary additional costs (Olsen, 2012).

Different companies also adopt support programs for coffee farmers in different areas, such as access to credit, business and risk management, adoption of sustainable farming techniques and techniques aimed at obtaining better coffee bean quality, among others (Badiyan-Eyford, 2013; Hernandez-Aguilera et al., 2018; Lautz, 2011). Others also assist coffee farmers in developing infrastructure at their farms for the incorporation of value-adding activities. Direct trade would then provide empowerment and important autonomy to coffee farmers, who could exercise a certain level of control in terms of trading and the destination of traded coffee (Leeson, 2013), reducing the power asymmetries in the supply chain (Olsen, 2012; Robbins, 2015).

All this would result in greater economic stability and viability of the activity. In turn, such factors would lead to improvement in the quality of life of coffee farmers and their family, and in a trickle-down effect, such benefits would reach rural workers and the community in general. Thus, there would be a tendency for coffee farmers to seek "stability, both in terms of workers and working conditions and in terms of the environment, especially since they are owners of the land and they are depending on that land to continue production next year" (Strand, 2014, p. 173). In this sense, it is noteworthy that there is a wide relationship between the benefits of relationships, quality and sustainability.

Direct trade also allows the participation of noncertified coffee farmers because buyers do not usually require these seals. Although they typically use certified coffees to diversify their product offerings, roasters and coffee shops do not consider them as a proxy for quality. Coffee farmers could then use such seals as voluntary indicators of the adoption of good environmental and social practices (Hotvedt, 2012; Schroeder, 2015). However, these agents usually consider the direct relationship with the coffee farmer and annual visits to farms as the most effective means to evaluate these criteria (Guimarães et al., 2016; Schroeder, 2015). The lack of certification requirements or even the nonestablishment of a certification specific for direct 
trade stimulates the participation of family farmers because such initiatives require "remuneration from often-impoverished farmers - either a fee, or increased transaction costs, or membership in a cooperative" (Hotvedt, 2012, p. 35-36). Because third parties do not certify it, direct trade avoids these costs and allows the maximization of coffee farmers' income (Hotvedt, 2012).

Such direct relationships also enable the traceability of the product and linking it back to its place of origin. Thus, "for customers who were not aware of the living conditions of people who work and live in coffee origins, talking about direct relationship of trading may invoke their empathy and initiate the reconsideration of their relationship with coffee, the mundane daily necessity" (Liu, 2016, p. 94).

This shows that direct trade is not strategic only in the purchasing of beans but also in the communication of the value proposition to final consumers, being an important form of product differentiation (Schroeder, 2015).
By selling highly differentiated coffees with emotional content (Samper et al., 2017), transferred directly to the consumer, roasters and coffee shops strengthen their brand and establish more stable relationships based on the loyalty of their customers, who value the product and pay a premium for it (Olsen, 2012). This premium runs through the supply chain until reaching the producer as a way of encouraging quality and the adoption of sustainable practices. Thus, "responsible practices become a natural part of business, entailing both upstream (stability, flexibility, skills upgrading) and downstream value (storytelling, branding, price rewards)" (Olsen, 2012, p.69).

\subsection{Limitations to direct trade}

We also subdivided the limitations to the practice of direct trade into three categories: "Conceptual and Regulatory", "Execution and Monitoring" and "Accessibility and Transformative Potential". As shown in Table 5, they were much less frequent than the benefits and potential of this trade model. 
Table 5 Categories, featured topics, and number of references about Direct Trade limitations

\begin{tabular}{|c|c|c|}
\hline Category & Featured topics & References \\
\hline \multirow[t]{2}{*}{$\begin{array}{l}\text { Implementation and } \\
\text { monitoring }\end{array}$} & \multirow[t]{2}{*}{$\begin{array}{l}\text { - } \quad \text { Cultural, structural and normative; } \\
\text { - } \quad \text { Financial, quality and supply risks; } \\
\text { - } \quad \text { Relationship and monitoring risks; } \\
\text { - } \quad \text { Production and pricing costs; } \\
\text { - } \quad \text { High investments and long-term results. }\end{array}$} & $\begin{array}{l}\text { Academic: A2, A4, A9, A10, A11, A12, } \\
\text { A20, A23, A25, A26, A27, A28, A29, } \\
\text { A32, A33, A34, A35, A36, A37, A38, } \\
\text { A45, A46, A47, A48, A49, A51, A52, } \\
\text { A53, A56 } \\
\text { Partial result*: } 29 \text { (51.8\%) } \\
\text { Partial result**: } 30.5 \% \\
\text { Technical: T2, T5, T8, T9, T11, T12, } \\
\text { T13, T18, T20, T23, T24, T25, T26, } \\
\text { T27, T28, T30, T31, T32, T33, T35, } \\
\text { T37, T39 } \\
\text { Partial result*: } 22(56.4 \%) \\
\text { Partial result**: } 23.2 \%\end{array}$ \\
\hline & & Total $* *: 53.7 \%$ \\
\hline \multirow[t]{2}{*}{ Conceptual and regulatory } & \multirow[t]{2}{*}{$\begin{array}{l}\text { - Multiple definition and inaccuracy of the } \\
\text { concept; } \\
\text { - Lack of regulation and accountability; } \\
\text { - Difficulty in measuring results and } \\
\text { accountability; } \\
\text { - Need for high engagement and consumer } \\
\text { education. }\end{array}$} & $\begin{array}{l}\text { Academic: A2, A3, A4, A9, A10, A13, } \\
\text { A14, A15, A16, A17, A20, A21, A23, } \\
\text { A25, A26, A27, A28, A29, A30, A32, } \\
\text { A33, A36, A37, A39, A40, A42, A45, } \\
\text { A46, A47, A48, A51, A53, A54, A56 } \\
\text { Partial result*: } 34(60.7 \%) \\
\text { Partial result**: } 35.8 \% \\
\text { Technical: T2, T3, T4, T6, T10, T11, } \\
\text { T13, T14, T16, T21, T29, T32, T39 } \\
\text { Partial result*: } 13(33.3 \%) \\
\text { Partial result**: } 13.7 \%\end{array}$ \\
\hline & & Total $* *: 49.5 \%$ \\
\hline \multirow[t]{2}{*}{$\begin{array}{l}\text { Accessibility and } \\
\text { transformation potential }\end{array}$} & \multirow[t]{2}{*}{$\begin{array}{l}\text { - Model accessibility and scalability; } \\
\text { - } \quad \text { Possible maintenance of power structures; } \\
\text { - } \quad \text { Restrictions on consumption; } \\
\text { - } \quad \text { t is not a unique solution; } \\
\text { - } \quad \text { Possibility of weakening collective initiatives }\end{array}$} & $\begin{array}{l}\text { Academic: } A 1, A 2, A 4, A 8, A 9, A 10, \\
A 14, A 15, A 16, A 18, A 19, A 20, A 21, \\
A 22, A 23, A 25, A 26, A 27, A 29, A 32, \\
A 37, A 38, A 42, A 45, A 47, A 48, A 51, \\
\text { A54 } \\
\text { Partial result*: } 28(50.0 \%) \\
\text { Partial result**: } 29.5 \% \\
\text { Technical: T8, T9, T11, T14 T17, T22, } \\
\text { T26, T32, T33, T38, T39 } \\
\text { Partial result*: } 11(28.2 \%) \\
\text { Partial result**: } 11.6 \%\end{array}$ \\
\hline & & Total**: $41.1 \%$ \\
\hline
\end{tabular}

* Among the same material category (i.e. academic or technical);

** Among total number of selected materials

The most prominent category refers to complications in the implementation and monitoring of direct trade, mentioned in $53.7 \%$ of the materials. Contact is usually initiated by roasters (Schroeder, 2015), who contact coffee farmers at trade fairs, coffee quality contests or through brokers (Daviron \& Ponte, 2013; Leeson, 2013). The costs for partner identification (searching costs or discovery costs) can be considered high (Samper et al., 2017; Schroeder,
2015), including the costs of participation in these events (e.g., international travel, tickets, demo product) and subsequent visits to farms and establishment of the relationship.

Moreover, identifying coffee farmers engaged in the production of specialty coffees is difficult. Because coffee bean trade usually occurs among agents of different nations, i.e., roasters/coffee shops 
in developed countries and coffee farmers in developing countries, linguistic, cultural and social barriers are often encountered (Sunderland, 2012), both in initiating contact between them and after the establishment of the business relationship and at the beginning of their partnership. Such differences, in some cases, lead to coffee farmers' distrust of foreign companies, making them choose to trade in local channels and cooperatives. Moreover, in some countries, such as Ethiopia (through the Ethiopia Commodity Exchange - ECX), there are also normative barriers (governmental norms regarding the export of the product) that hinder or even make this practice unfeasible (Schroeder, 2015).

To implement direct trade, it is necessary for all agents to make high financial, time and dedication investments. The production of specialty coffees and constant improvement in the product result in higher production costs and often require the adoption of new production techniques or investments in farm infrastructure, which only produce long-term results (Olsen, 2012). This, in turn, results in significant financial, quality and supply risks in addition to less reaction time and flexibility to market demands and limited turnover (Lukas, 2015).

Because coffee is an agricultural product, coffee is subject to weather, pests, diseases and other factors that can both lead to loss of quality and production volume. The very concept of quality, which has a strong subjective component, represents a difficulty for direct trade, as it hinders the exchange of knowledge between coffee farmers and roasters. It also affects the establishment of pricing criteria. Ideally, coffee farmers should have the same ability to evaluate product quality and the same bargaining power as their partners (Leeson, 2013), which often does not happen.

The volume of product purchased by the roasters also represents a limitation to this trade model. To provide sensory diversity to their consumers, these companies constantly purchase small volumes from a variety of coffee farmers from different regions. Thus, it is infrequent that a roaster acquires the entire crop from a coffee farmer, which occurs only in the case of small family farms (Schroeder, 2015). In other cases, the roasting companies are small, and some authors suggest that for the direct trade relationship to be successful, the ideal scenario would be that the medium-sized roaster companies trading with family coffee farmers (Olsen, 2012).
The implementation of direct trade also comes with significant relationship and monitoring risks (Schroeder, 2015). It is necessary to establish, in advance, which agent will absorb the losses resulting from nonconformity with the expected results of product quality and quantity. Roasters often require coffee farmers to invest in specific production practices that sometimes do not generate the expected results, and in these cases, they simply do not purchase the product, thus making their commercial partner more vulnerable, especially in the case of family farmers. In other cases, agents downstream of the chain invest significantly in improving the structure and processes of the farm but without getting the exclusive rights to that coffee in the region and are thus at a competitive disadvantage.

In addition, there is always the risk of noncompliance with contracts (often informal/verbal and negotiated annually), leading to the need for constant monitoring. In this case, it is important to emphasize the dualistic perception of contracts: on the one hand, they are important to minimize risks and to facilitate the planning of activities by agents and, consequently, access to financing (Daviron \& Ponte, 2013); on the other, mutual trust and commitment are the bases of the relationship between agents (Borrella et al., 2015).

The second category of relevant limitations relates to conceptual and regulatory difficulties, which are closely connected. There are varied conceptions of this form of trade, which indicates the existence of more than one direct trade model (Daviron \& Ponte, 2013; Olsen, 2012). It would be more prudent, therefore, to speak of $a$, rather than the, direct trade model (Olsen, 2012).

Different authors consider the concept of direct trade imprecise. This is because the direct trade narrative is usually presented as composed of three main actors: the coffee farmer, the roaster and the barista or consumer (Holland, Kjeldsen \& Kerndrup, 2015). However, other actors are still needed, both in producing and importing countries, to enable direct trade, something that the term "direct" easily obscures (Borrella et al., 2015; Holland et al., 2015; Robbins, 2015; Rosenberg, Swilling \& Vermeulen, 2018; Samper et al., 2017). As shown by Borrella et al. (2015), the barriers to market access usually faced by coffee farmers are of two types: physical/structural or informational. To overcome these barriers, it is 
possible to resort to intermediaries, which the authors call connective businesses. These can be involved in providing credit to farmers as well as infrastructure for processing and evaluation of coffee beans, in addition to sharing market information, "translating" them in terms of quality and other attributes in order to facilitate understanding. Connective businesses also provide support for the export/import of the product, unviable activities for most coffee farmers and roasters because of their complexity and bureaucracy.

This does not mean that the contact and relationship between coffee farmers and roasters is not direct. As highlighted by Olsen (2012, p. 79), "middlemen are for the majority of cases not excluded to cut back on costs, although it is a benefit, so much as it is about improving communication between the most essential value chain members". As long as such businesses contribute to achieving the quality and consistency of coffee bean supply, without hindering the flow of information and contact between agents, there is no need to exclude them from the transaction.

Unlike certifications, such as Fairtrade, direct trade does not have a regulatory agency that establishes a common definition and its implementation criteria and that verifies the conformity of the role of its members (Gyllensten, 2017; Hotvedt, 2012; Schroeder, 2015). The high adaptability of direct trade to local realities, one of its main contributions, also makes it difficult to establish criteria for verification and measurement of its results, which hinders the scalability of the model (Olsen, 2012).

The certifications are expensive and highly bureaucratic, diverting the focus from the essence of the model (Hotvedt, 2012; Olsen, 2012), and do not ensure conformity with quality standards (MacGregor et al., 2017). Nevertheless, some companies seek third party auditing to verify their direct trade models or have sought to trademark the term to restrict its use, with different levels of success (Holmberg, 2011; Hotvedt, 2012; Leeson, 2013; MacGregor et al., 2017). Such strategies, however, are exceptions in this market, whose actors usually opt for a more liberal approach to voluntary sustainability models (MacGregor et al., 2017), especially because they have arisen from a perception of inefficiency of local governments and certifiers in achieving such an objective (BadiyanEyford, 2013; Kolk \& Lenfant, 2016).

The accountability of actors for the practices and disclosed results is somewhat difficult to achieve, and its monitoring is normally performed internally and with little transparency, opening space for the misuse of the term "direct trade" to differentiate the product and win new customers (Gyllensten, 2017; MacGregor et al., 2017). The nebulosity and misuse of the concept lead to the deterioration of the term and its loss of credibility, enabling opportunism by certain agents and the cooptation of the movement (MacGregor et al., 2017; Olsen, 2012). For this reason, some pioneering companies in direct trade have minimized or even abolished the use of the term to define their coffee purchasing practices (MacGregor et al., 2017).

In this sense, some players seek to minimize such effects through direct disclosure to consumers of information about their relationships with coffee farmers, including the price paid for the product, either in its packaging, in their social media profiles, or through the disclosure of annual transparency and sustainability reports (MacGregor et al., 2017). Others invite consumers to 'see for themselves' the relationship between coffee farmers and their results (Lautz, 2011, p.31) through programs such as 'get to know the coffee farmer' (Parker, 2011). Thus, these agents seek a consumer-driven (Cole, 2014) or "consumer-certified" (Lautz, 2011) transformative model instead of expecting them to rely on thirdparty certifications unknown to them. However, some authors argue that such a stance "overburdens" consumers by delegating to them the responsibility of monitoring the disclosed data and overseeing the company's stance through purchasing practices (Liu, 2016; MacGregor et al., 2017).

The last category of limitations, addressed by $41.1 \%$ of the analyzed materials, refers to the accessibility of agents to this practice and its transformative potential. The need for high initial investments and the complexity of knowledge about specialty coffees limits the access of its agents (Lukas, 2015). In the case of coffee farmers, a minimum quality level prior to the establishment of the business relationship (Badiyan-Eyford, 2013) and the location of the farmer in a recognized place of origin (Fischer, 2017) are necessary. The level of education of coffee farmers, their ability to use technology and their ability to understand the concepts of quality, 
translating them into practices that add value to the product, also influence the successful adoption of direct trade (Fischer, 2017; Gyllensten, 2017).

Thus, the main beneficiaries of direct trade have been the medium producers, or the "largest among the small", which hold social capital that allow them to present an attractive image of production and quality to developed markets (Fischer, 2017). They also have easier access to credit, markets and infrastructure, and greater potential for achieving consistent quality (Daviron \& Ponte, 2013; Liu, 2016; Robbins, 2015; Schroeder, 2015). The absence of these features limits access for small coffee farmers, the most vulnerable in this chain and those whom the original direct trade model proposes to help.

In the case of roasters and coffee shops, the high financial investment and the need for constant monitoring can make direct trade unfeasible for small companies, and more easily adopted by medium and large organizations (Olsen, 2012). The scalability of the model, i.e., its adoption by a large number of agents, is therefore undermined.

Additionally, the high price of direct trade coffees, usually from microlots, is prohibitive for many consumers, limiting their consumption by a large majority of the population. In addition, "consumers need to feel comfortable extensively interacting with roasters and baristas, participating in cupping events, or researching on their own" (Hotvedt, 2012, p. 59). The level of knowledge about the product is also highly variable among consumers, suggesting that the benefits of direct trade are more highly concentrated at the beginning than at the end of the supply chain (Olsen, 2012).

Another concern relates to the maintenance of power structures (Gyllensten, 2017) because in most cases, it is still downstream actors that determine the terms of trade and, more importantly, the criteria for assessment of product quality and pricing, with farmers being left to adapt to a pre-established model (Cole, 2011; Leeson, 2013; Liu, 2016; Sunderland, 2012). Roasters also have the power to reject the product or terminate the relationship if their expectations are not met (Cole, 2014); these agents have greater knowledge of the global coffee market, closer contact with end consumers and greater financial security (Schroeder, 2015).

The specialty coffee market represents only approximately $10 \%$ of the world's coffee consumption, not currently absorbing all the production of these beans. Thus, even specialty coffee producers should not ignore the mainstream market and, instead, trade in both (Borrella et al., 2015).

All these limitations suggest that direct trade, despite its significant contributions, is not a single solution to the problems faced by coffee farmers (Olsen, 2012), requiring its adoption in collaboration with well-developed institutional environments and other support institutions.

\subsection{New lines of research}

As highlighted by Samper and Quiñones-Ruiz (2017, p. 15), "clearly, we are at a critical junction to review the current coffee sustainability model and evaluate possibilities for improvement". Direct trade appears to be a possibility for transforming this supply chain but has been little addressed in the scientific literature (Leeson, 2013; Schroeder, 2015), leaving many theoretical and empirical gaps to be filled in future studies.

The first step is to identify and understand the technological, environmental, social and economic conditions that stimulate or limit the production of specialty coffees and the adoption of direct trade by coffee farmers and green coffee buyers (Bro \& Clay, 2017; Hernandez-Aguilera et al, 2018). Furthermore, it is necessary to identify and evaluate the real environmental, social and economic impacts of direct trade, such as the payment of higher prices for the product, coffee farmers' empowerment and the increase in their bargaining power. In addition, it is necessary to assess the improvement of the quality of life of the rural community and the compliance with sustainability criteria (Badiyan-Eyford, 2013; Borrella et al., 2015; Bro \& Clay, 2017; HernandezAguilera et al., 2018). One way to assess the promotion of equity in the supply chain would be to evaluate the percentage of income accrued per agent, considering the costs of each actor, the amounts involved and applying the purchasingpower parity principle (Borrella et al., 2015). In addition, it is valid to adopt a longitudinal perspective for case studies on the adoption of direct trade and the duration of such relationships and their real effects (Strand, 2014).

The comparison of these impacts to those obtained with certifications or the implementation of 
other initiatives to promote the sustainability of the supply chain also demands attention by researchers, since it would allow a better understanding of the real potential of direct trade (Olsen, 2012) and an assessment of the complementarity or substitutability between initiatives. The evaluation of such impacts represents an important challenge for those involved in direct trade, but they could get inspiration from the Sustainable Coffee Challenge or Global Coffee Platform methodologies to ensure a balance between the interests of the industry and society (Gheibi, Kazaz \& Webster, 2017).

As the concept of direct trade is still significantly variable, its forms of implementation and empirical issues, which are rarely addressed, such as the development and use of methods to ensure transparency and accountability by its agents, should be thoroughly researched (Badiyan-Eyford, 2013; Lautz, 2011).

It is also evident the need for a better understanding of the role of connective businesses, their socioeconomic impacts in the rural community (Borrella et al., 2015) and their influence in the creation of material quality. This "will require immersive, country-specific research, given that unlike sustainability standards - the production of taste is unique to place" (Rosenberg et al., 2018, p. 209).

Other issues include the analysis of "costs, risks and trade-offs of specific management practices associated with product quality as well as the implications of alternative allocation of price premiums" (Hernandez-Aguilera et al., 2018, p.193). A major contribution would be the development of a pricing model that considers the production costs of coffee farmers and the cost of living in their community so that they can achieve an adequate quality of life. This model should also consider the specificities of the buyer and their economic power to align the expectations and economic capacities of the agents involved, reducing the inequality of the supply chain and promoting its development.

Much of the academic literature available on direct trade considers the perspective of companies that use this approach, neglecting the perspective of other agents (Leeson, 2013). Thus, we recommend greater attention to the perceptions of coffee farmers, connective businesses and consumers (Borrella et al., 2015; Leeson, 2013; Olsen, 2012).
It is important to incorporate the perspective of coffee farmers into the model, especially regarding their socioeconomic realities (Lautz, 2011), as well as of consumers, to understand their opinions and levels of knowledge on direct trade. Currently, there is a wide discrepancy between the awareness of roasters and consumers about the socioeconomic and environmental problems of the coffee supply chain (Olsen, 2012), and it is necessary to investigate effective ways of transmitting this information to promote "consumer education".

Another important issue neglected in the literature refers to the variability in the characteristics of coffee farmers from different nations or even wide differences in the social and economic conditions of farmers from different regions of the same country.

Therefore, the important strategic function of direct trade, related to ensuring the supply of coffee with exceptional quality (Schroeder, 2015), has been underestimated, assumption confirmed in this study, since the "Quality and Differentiation" category was the least addressed in the literature, among the categories analyzed regarding the benefits of direct trade.

Moreover, possible adoption of direct trade by larger companies (Borrella et al., 2015; Schroeder, 2015) has not received sufficient attention in the literature. The scalability of the model, as well as its potential to deviate from the initial values and guiding principles of the movement, as occurred with fair trade, demands further studies.

Thus, it is important to understand direct trade in addition to its aspects related to the sustainability of the chain, making sure to encompass all the dimensions of this trade model in any new attempts to define its concept (Schroeder, 2015).

Finally, the study of direct trade should be expanded to other products (Hernandez-Aguilera et al., 2018; Olsen, 2012; Schroeder, 2015), such as cocoa for the production of fine chocolates, a market in which have emerged "bean-to-bar" companies that adopt practices similar to those identified in the specialty coffee market (Schroeder, 2015). Once more, coffee is a pioneer in the adoption and diffusion of initiatives aimed at promoting the sustainability of supply chains. 


\subsection{General Considerations}

For MacGregor et al. (2017), the discussions on direct trade become confusing by the use of the term in three distinct ways. First, as a general trade model, supported by direct and regular contact between coffee farmers and roasters. Second, as a marketing strategy, focused on product differentiation for the consumer, and finally as a voluntary sustainability standard, assuming the fulfillment of certain guidelines. Considering the information presented above and to clarify such issues, it is necessary to reformulate the concept of direct trade presented in the literature to encompass all its dimensions, as suggested by Schroeder (2015). Therefore, from this moment on, the following definition will be used (Table 6).

Table 6 Proposal for a new concept of direct trade for agricultural products, based on coffee

Direct trade is a market arrangement composed of agents related to the specialty coffee market that, through the shortening of the supply chain, seek to improve its coordination and transparency, ensuring the supply of high-quality coffees, only achieved through the promotion of economic, social and environmental sustainability of coffee production.

In this concept, there is a primacy of the strategic dimension of direct trade over the ethical aspects of trading, despite their importance. In other words, sustainability is seen a means to achieve the primary objective of these agents, related to the guarantee and consistency of supplying exceptional quality coffees.

Furthermore, it highlights the shortening of the supply chain without eliminating all intermediaries between coffee farmers and roasters, recognizing their role as facilitators of trade. The central idea would be to maintain only those intermediaries that do not affect the transparency of the chain and that do not take advantage of information asymmetries or other factors to appropriate most of the value generated (Gyllensten, 2017).

Based on this new concept, in the selected materials and in the contributions, limitations and new lines of research identified, we propose two theoretical advances in the study of direct trade. The first of these refers to its classification into two categories: a) relational direct trade (RDT) and b) transactional direct trade (TDT). The second advance consists of the division of this arrangement, be it relational or transactional, into five stages, which facilitate the understandability and study of direct trade. We present these advances separately in sections 4.4 .1 and 4.4.2, below.

4.4.1 Direct trade and its relational and transactional perspectives

We identified two ways of adopting direct trade. The first relates to the model originally conceived by third-wave coffee shops, herein called Relational Direct Trade, which involves a direct and long-term relationship between coffee farmers and roasters/coffee shops based on principles of mutual trust and collaboration. Different studies refer to this "hands on" direct trade model as Relationship Coffee and consider the relationship between coffee bean quality and sustainable and regional development of the activity as paramount. In the case of a breach of contract due to issues outside the control of the coffee farmer, their partners usually absorb the costs or split them with the producers so as not to impede the continuity of production. In this model, maximum coffee quality is still essential, but other factors, such as the quality of life of coffee farmers and the wellbeing of their community, also receive great attention.

The second model, herein called Transactional Direct Trade, can be considered "hands off", superficial or of low engagement. It seeks to eliminate intermediaries, to bring together agents and consequently to improve their coordination, but the focus is only on producing high-quality coffees. In the case of unforeseen circumstances, the coffee farmer alone is liable for any losses. In this model, the actors downstream of the supply chain invest only in factors that will add direct value to the product. In these cases, the practice is often referred to as "more direct trade".

In this sense, some considerations are necessary. Do the benefits of RDT lead to TDT? This is because RDT's goal, in addition to guaranteeing the supply of exceptional coffees, is the promotion of social, environmental and economic sustainability of the chain. The empowerment of coffee farmers, based on the achievement of these goals, could make the relations more focused on the more technical aspects of the product and trade. 
Another hypothesis consists of the perception of the models as completely different perspectives, where the incidence of RDT is less common due to the high time and financial investments required for its implementation. Additionally, as previously discussed, direct trade is more easily adopted by medium to large-sized farms and roasters or coffee houses and is difficult to implement by third-wave coffee agents.

\subsubsection{The stages of direct trade implementation}

This study proposes, regardless of its relational or transactional perspective, the division of the practice of direct trade into seven stages (Figure 2), which help in understanding and studying this specialty coffees' trade model. The first stage refers to the first contact or experience of the agent (coffee farmer, roaster/coffee shop or connective business) with direct trade, something not yet explored in the consulted literature. Subsequently, once actors get to know the benefits attributed to this trade model, they identify the need for its adoption, and start searching for related information.
In the second stage, the agent seeks to identify possible direct trade partners, which occurs mostly through participation in quality contests or coffeerelated fairs and, at a lower level, through the referral of other professionals or through brokers. In this stage, there are difficulties associated with cultural and linguistic barriers and financial constraints because a large number of agents do not have sufficient capital for frequent international travel and participation in fairs/contests. At this moment, agents seek the alignment of their expectations and interests and, to the extent possible, assess the compatibility of their values.

Once a direct trade partner is selected, the development of a relationship between the parties begins, and the rules that guide the practice are defined (e.g., establishment of formal contracts or verbal agreements, creation of pricing scales, establishment of quality criteria, etc.). In this stage, one (TDT) or both parties (RDT) will start investing time, effort and capital to achieve the predetermined quality. 
Figure 2 - Implementing stages of Direct Trade.

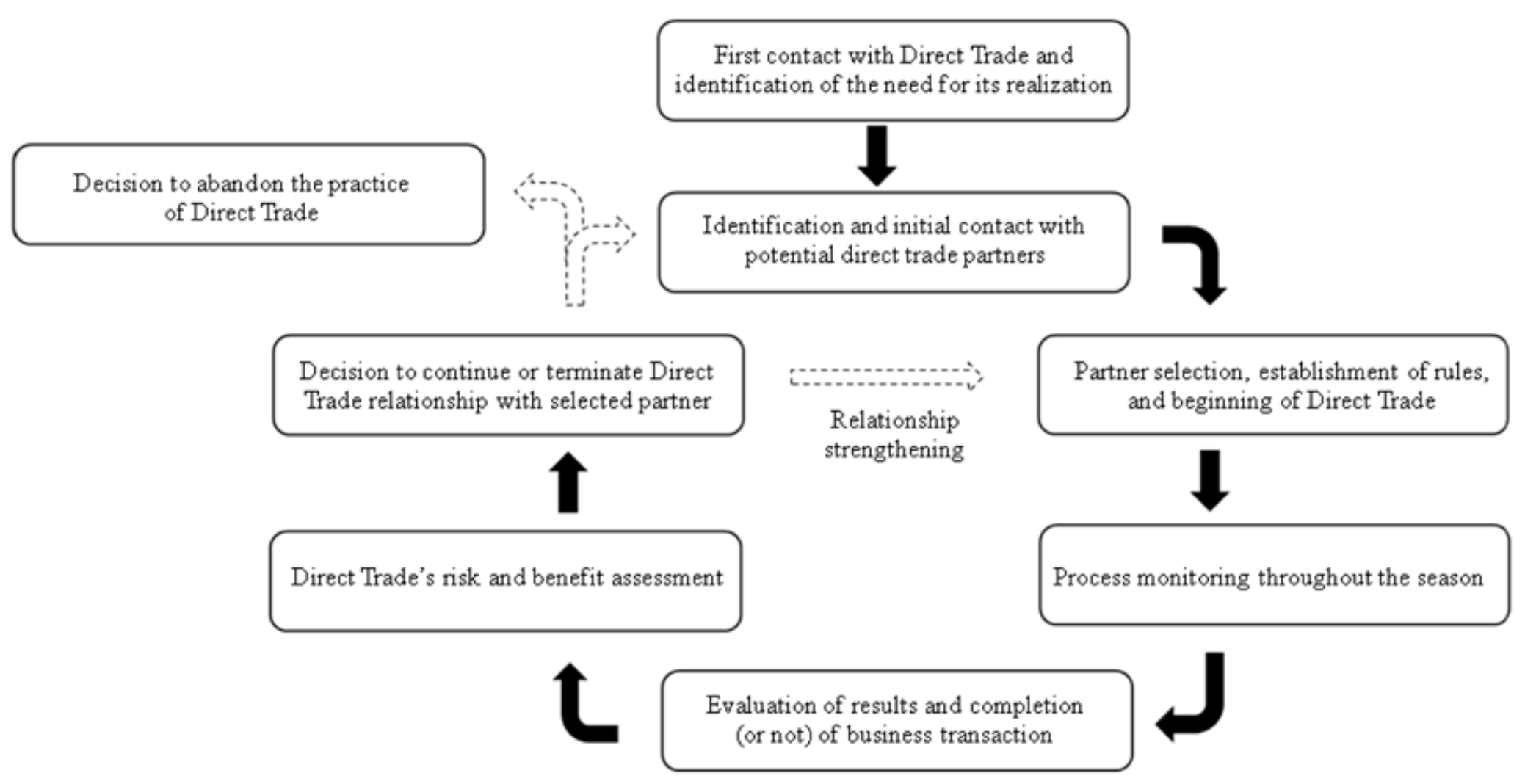


Throughout and at the end of the harvest, the results are monitored and evaluated - essentially related to quality improvements, attractive prices and increased (economic, social and environmental) sustainability of the activity - comparing them to predetermined criteria and thus deciding whether or not to purchase the beans. If there is still no established price, that takes place in this stage, with evaluation of the product by roasting the samples and subsequent tasting, jointly between the agents or individually by the roaster.

At the end of each harvest or trade, each agent individually evaluates the benefits obtained and risks incurred by the adoption of direct trade. If the actors' expectations are not met, the transactions between them are terminated or the terms of the contract (whether formal or informal) are renegotiated in case of occurrence of factors beyond their control (weather, pests and diseases, etc.). If the results meet actors' expectations, they renew the agreement for another harvest. In such cases, there is a strengthening of the relationship between the actors and intensification of joint work among them, based on the principles of trust and transparency. Notably, this is usually a cyclical process because of the tendency, identified in the consulted literature, to develop new direct trade partnerships once they stabilize the previous relationship.

The possible presence and/or influence of connective businesses (Borrella et al., 2015) in all these steps is noteworthy. However, their role still needs thoroughly investigation in future studies.

\section{CONCLUSIONS}

Direct trade is a recent initiative aimed at promoting the environmental, social and economic sustainability of coffee production. Established in the 1990s, it has recently gained prominence in the technical and scientific literature, but studies and discussion on the topic are still superficial and fragmented. Through the first systematic review of the literature on the subject, we sought to understand and systematize the main benefits and limitations of direct trade, categorizing and demonstrating their interconnection. Its main benefits relate to the coordination and relationship between agents, appreciation of the origin and promotion of sustainability and, finally, product differentiation and consistency of the supply of exceptional quality coffees. Limitations, in turn, are associated with difficulties in its implementation and monitoring, conceptual and regulatory constraints, and its accessibility and transformative potential. Moreover, this study identified several theoretical and empirical gaps that should be investigated in future studies.

Based on the literature consulted, a new definition of direct trade was proposed to emphasize its strategic dimension, largely ignored until now (Schroeder, 2015), and to recognize the important function of certain connective businesses (Borrella et al., 2015) that persist in the coffee supply chain, usually hidden by the imprecision of the term. We presented two forms of its adoption: the relational form characterized by high engagement and collaborative work to promote sustainability in the chain, and the transactional approach, with low engagement and focused only on ensuring the supply of specialty coffees. Furthermore, we subdivided its implementation into seven stages to help understand the trade model and support future work.

This work presents important theoretical and empirical/managerial contributions. In theoretical terms, the establishment of a more precise concept of this practice, as well as synthesis of its main contributions and limitations, assists in future work on the theme, also inspired by the research gaps identified here. In empirical/managerial terms, this work can assist the actors in the international specialty coffee market in deciding whether to adopt Direct Trade and in establishing strategies to start the practice, aligning its expectations about the possible results. In addition, Direct Trade practitioners might better understand other actors' perspective, thus reflecting on the practice and working to improve it.

However, it was not possible to identify all studies effectively related to one or more forms of implementation of direct trade due to the lack of consensus about its concept and the practices that characterize it. Therefore, the reflections presented have great potential for helping understand this trade model, its benefits and limitations, thus laying the foundation for future studies.

As another limitation of the study, we highlight the high number of works in process to compose the body of selected materials. Therefore, this paper may be best understood as an attempt to present the indications of research carried out in scientific studies that point to a trend, but are not, yet, the state of the art about Direct Trade. In addition, we highlight that 
we based our conclusions on different sources, including articles in reputable journals, which slightly reduces this vulnerability. Therefore, in future

\section{REFERENCES}

Adams, R.J., Jeanrenaud, S., Bessant, J., Overy, P., \& Denyer, D. (2012). Sustainability oriented innovation: a systematic review. International Journal of Management Reviews, 18(2), pp. 180-205.

Adams, R. J., Smart, P., \& Huff, A. S. (2017). Shades of Grey: Guidelines for Working with the Grey Literature in Systematic Reviews for Management and Organizational Studies. International Journal of Management Reviews, 19, 432-454.

Akiyama, T. \& Varangis, P. N. (1990). The impact of the international coffee agreement on producing countries. The World Bank Economic Review, 4(2), 157-173.

Auld, G. (2010). Assessing certification as governance: effects and broader consequences for coffee. The Journal of Environment \& Development, 19(2), 215-241.

Bacon, C. M., Méndez, V. E., Gómez, M. E. F., Stuart, D., \& Flores, S. R. D. (2008). Are sustainable coffee certifications enough to secure farmer livelihoods? The millennium development goals and Nicaragua's Fair Trade cooperatives. Globalizations, 5(2), 259-274.

Badiyan-Eyford, J. (2013). Direct trade coffee: prospects and pitfalls. Dissertation (Master of Arts) University of Calgary, Alberta, Canada.

Barham, B. L., \& Weber, J. G. (2012). The economic sustainability of certified coffee: Recent evidence from Mexico and Peru. World Development, 40(6), 1269-1279.

Bastos, M. H. R., de Oliveira, U. R., Souza, T. C. R., dos Santos, R. F., \& do Lago, M. M. (2019). Análise de discurso e Análise de Conteúdo: Um levantamento de suas aplicações nas ciências aplicadas membros da Administração. Brazilian Journal of Development, 5(11), pp. 26301-26322. studies, we recommend that researchers subject the conclusions of this study to empirical testing and seek their validation by specialty coffee professionals.

Boaventura, P. S. M., Abdalla, C. C., Araújo, C. L., \& Arakelian, J. S. (2018). Value Co-Creation in the Specialty Coffee Value Chain: The Third-Wave Coffee Movement. Revista de Administração de Empresas, 3(58), 254-266.

Bode, R., \& Piechaczek, J. (2007). Innovations towards product differentiation - farmers associations' strategies to integrate into specialty coffee value chains. In: Anais Conference on International Agricultural Research for Development, Göttingen.

Borrella, I., Mataix, C., \& Carrasco-Gallego, R. (2015). Smallholder farmers in the speciality coffee industry: opportunities, constraints and the businesses that are making it possible. IDS Bulletin, 46(3), 29-44.

Botelho, L. L. R., Cunha, C. C. de A., \& Macedo, M. (2011). O método da revisão integrativa nos estudos organizacionais. Gestão e Sociedade, 5(11), 121-136.

Bro, A., \& Clay, D. C. (2017). Transforming Burundi's coffee sector through strategic value chain investments. Journal of Agribusiness in Developing and Emerging Economies, 7(3), 218-230.

Cavalcante, R. B., Calixto, P., \& Pinheiro, M. M. K. (2014). Análise de conteúdo: considerações gerais, relações com a pergunta de pesquisa, possibilidades e limitações do método. Informação \& Sociedade, 24(1), pp. 13-18.

Caregnato, R. C. A., \& Mutti, R. (2006). Pesquisa qualitativa: análise de discurso versus análise de conteúdo. Texto \& Contexto - Enfermagem, 15(4), 679-84.

Carvalho, J. P. (2016). Campo organizacional e adoção de Indicação Geográfica (IG): um estudo sobre a produção de cafés especiais no Brasil. Tese (Doutorado em Administração de Organizações) Universidade de São Paulo, São Paulo, Brasil.

Clarke, N., Barnett, C., Cloke, P., \& Malpass, A. (2007). The political rationalities of fair-trade 
consumption in the United Kingdom. Politics \& Society, 35(4), 583-607.

Cluley, R. (2018). The construction of marketing measures: The case of viewability. Marketing Theory, 18(3), pp. 287-305.

Campos, C. J. G. (2004). Método de análise de conteúdo: ferramenta para a análise de dados qualitativos no campo da saúde. Revista Brasileira de Enfermagem, 57(5), 611-614.

Cole, N. L. (2014). Ethical Consumption in the Global Age: Coffee's Promise of a Better World. In: N. Mathur. Consumer Culture, Modernity, and Identity (pp. 318-344). New Delhi: Sage Publications.

Daviron, B., \& Ponte, S. (2013). The coffee paradox: global markets, commodity trade and the elusive promise of development. London: Zed Books.

Dorval, M., Jobin, M., \& Benomar, N. (2019). Lean culture: a comprehensive systematic literature review. International Journal of Productivity and Performance Management, 68(5), pp. 920-937.

Edelmann, H., Quiñones-Ruiz, X. F., \& Penker, M. (2020). Analytic framework to determine proximity in relationship coffee models. Sociologia Ruralis, 60(2), 458-481.

Esmaeili, L., \& Hashemi G., S. A. (2019). A systematic review on social commerce. Journal of Strategic Management, 27(4), pp. 317-355.

Fischer, E. F. (2017). Quality and inequality: taste, value, and power in the third wave coffee Market. MPIfG Discussion Paper, 17(4), 1-36.

Folmer, B., Blank, I., Farah, A., Giuliano, P., Sanders, D., \& Wille, C. Introduction. In:

Folmer, B. (Ed.). The craft and science of coffee. London: Academic Press.

Foster, D. L. (2011). From crop to cup: the plight of coffee. Dissertation (Master of Sciences) University of Montana, Missoula, USA.

Gerard, A.; Lopez, M. C. \& McCright, A. M. (2019). Coffee Roasters' Sustainable Sourcing Decisions and Use of the Direct Trade Label. Sustainability, 11(19), 5437.
Gheibi, S., Kazaz, B., \& Webster, S. (2017).Direct trade and the third-wave coffee: sourcing and pricing a specialty product under uncertainty. Syracuse: Syracuse University.

Gilbert, C. L. (1996). International commodity agreements: an obituary notice. World Development, 24(1), I-19.

Guimarães, E. R., Castro Júnior, L. G., \& Andrade, H. C. C. (2016). A Terceira Onda do Café em Minas Gerais. Organizações Rurais \& Agroindustriais, 18(3), pp. 214-227.

Gyllensten, B. (2017). Micro mills, specialty coffee and relationships: following the supply chain from Costa Rica to Norway. Dissertation (Master of Culture, Environment and Sustainability) - University of Oslo, Oslo, Norway.

Hernandez-Aguilera, J. N., Gómez, M. I., Rodewald, A. D., Rueda, X., Anunu, C., Bennett, R., \& Es, H. M. (2018). Quality as a driver of sustainable agricultural value chains: the case of the relationship coffee model. Business Strategy and the Environment, 27(2), 179-198.

Holland, E., Kjeldsen, C., \& Kerndrup, S. (2015). Coordinating quality practices in Direct Trade coffee. Journal of Cultural Economy, 9(2), 1-11.

Holmberg, S. R. (2011).Solving the "coffee paradox": understanding Ethiopia's coffee cooperatives through Elinor Ostrom's theory of the commons. Thesis (Doctorate in Philosophy) University of Massachusetts, Amherst, USA.

Hotvedt, M. E. (2012). Buy global, think local: direct trade coffee and community renaissance in Olympia, Washington. Thesis (Doctorate in History) Claremont McKenna College, Claremont, USA.

Kallio, H., Pietilä, A. M., Johnson, M., \& Kangasniemi, M. (2016). Systematic methodological review: developing a framework for a qualitative semi-structured interview guide. Journal of Advanced Nursing, 72(12), 2954-2965.

Kolk, A., \& Lenfant, F. (2016). Hybrid business models for peace and reconciliation. Business Horizons, 59(5), 503-524. 
Latta, P. (2014). Direct trade: the new fair trade. Global Societies Journal, 2(1), 1-18.

Lannigan, J. (2020). Making a space for taste: Context and discourse in the specialty coffee scene. International Journal of Information Management, $51,101987$.

Lautz, B. A. (2011). Fair trade and development goals in the coffee sector. Dissertation (Master of International Studies) - DePaul University, Chicago, USA.

Leeson, M. (2013). Burundi in the World of Direct Trade and specialty coffee. Dissertation (Master in Philosophy) - University of Oslo, Norway.

Liu, Y. (2016). Configuring the qualification of good coffee: an ethnography on the specialty coffee industry in Milwaukee. Dissertation (Master of Sciences) - University of Wisconsin, Milwaukee, USA.

Lukas, K. D. (2015). The supply chain of fair trade coffee: challenges, opportunities \& the future inside a troubled industry. Dissertation (Master of Sciences) University of Vermont, Burlington, USA.

Macgregor, F., Ramasar, V., \& Nicholas, K. A. (2017). Problems with firm-led voluntary sustainability schemes: the case of direct trade coffee. Sustainability, 9(4),2017.

Nandonde, F. A., \& Kuada, J. (2016). International firms in Africa's food retail business-emerging issues and research agenda. International Journal of Retail \& Distribution Management, 44(4), pp. 448-464.

Olsen, A. (2012). H. Analysing the Direct Trade Model: a study of a promising market based trend in ethical coffee sourcing. Dissertation (Master in Business Studies and Development) -Copenhagen Business School, Copenhagen, Denmark.

Panhuysen, S., \& Pierrot, J. (2018). Coffee Barometer 2018. The Hague: Hivos.

Parker, S. F. (2011). How good the coffee can be. An interview with Stumptown's Matt Lounsbury. In: Parker, S. F. \& Austin, M. W. (Ed.). Coffee: philosophy for everyone. (pp. 166-173). West Sussex: WileyBlackwell.
Perez, J., Kilian, B., Pratt, L., Ardila, J. C., Lamb, H., Byers, L., \& Sanders, D. (2017). Economic sustainability - price, cost and value. In: Folmer, B. (Ed.) The craft and science of coffee. (pp. 133-158). London: Academic Press.

Pulido, M. (2017). Formulating a strategy for an ecommerce of specialty coffee - case: startup company the Netherlands. Dissertation (Master of International Business Management) -Haaga-Helia University of Applied Sciences, Malmi, Finland.

Robbins, T. (2015). The specialty question: economic empowerment in the Colombian Coffee lands. Dissertation (Master of Arts) - Wesleyan University, Middletown, USA.

Rosenberg, L., Swilling, M., \& Vermeulen, W. J. V. (2018). Practices of third wave coffee: a burundian producer's perspective. Business Strategy and the Environment, 27(2), 199-214.

Samper, L. F., Giovannucci, D., \& Vieira, L. M. (2017). The powerful role of intangibles in the coffee value chain. Geneva: World Intellectual Property Organization.

Samper, L. F., \& Quiñones-Ruiz, X. F. (2017). Towards a balanced sustainability vision for the coffee industry. Resources, 6(2), 1-28.

Schroeder, S. (2015). When ethics are good for business: a case study on the strategic importance of direct trade for three speciality coffee roasters in Copenhagen. Dissertation (Master of Business, Language and Culture) - Copenhagen Business School, Denmark.

Strand, E. (2014).Understanding differentiated coffee: a value chain perspective. Dissertation (Master of International Business and Marketing) University of Nordland, Bod $\varnothing$, Norway.

Sunderland, S. (2012). Trading the happy object: coffee, colonialism, and friendly feeling. M/C Journal, 15(2), 1-3.

Tranfield, D., Denyer, D., \& Smart, P. (2003). Towards a methodology for developing evidenceinformed management knowledge by means of systematic review. British Journal of Management, 14, pp. 207-222. 
Vicol, M., Neilson, J., Hartatri, D. F. S., \& Cooper, P. (2018). Upgrading for whom? Relationship coffee, value chain interventions and rural development in Indonesia. World Development, 110, 26-37.
Watts, G. (2013). Direct Trade in coffee. In: Thurston, R. W., Morris, J., \& Steiman, S. (Ed.).Coffee: a comprehensive guide to the bean, the beverage, and the industry. (pp. 138-144). Maryland: Rowman \& Littlefield.

\section{About the authors:}

Elisa Reis Guimarães - Universidade Federal de Lavras - UFLA, Minas Gerais, (Brasil). Email: elisa.rguimaraes@ufla.br. Orcid id: https://orcid.org/0000-0003-4917-5218

Antônio Carlos dos Santos - Universidade Federal de Lavras - UFLA, Minas Gerais, (Brasil). Email: acsantos@ufla.br. Orcid id: https://orcid.org/0000-0002-7499-5034

Paulo Henrique Montagnana Vicente Leme - Universidade Federal de Lavras - UFLA, Minas Gerais, (Brasil). Email: paulo.leme@ufla.br. Orcid id: https://orcid.org/0000-0003-4174-5642

Angélica da Silva Azevedo - Universidade Federal de Lavras - UFLA, Minas Gerais, (Brasil). Email: angelica.soad@gmail.com. Orcid id: https://orcid.org/0000-0003-2175-594X

APPENDIX A - List of selected academic materials

\begin{tabular}{|c|c|}
\hline Code & Reference \\
\hline A1 & $\begin{array}{l}\text { Ayöz, S. (2018). Coffee is the new wine: an ethnographic study of third wave coffee in Ankara } \\
\text { (Master's Thesis, Middle East Technical University, Ankara, Turkey). }\end{array}$ \\
\hline A2 & $\begin{array}{l}\text { Badiyan-Eyford, J. (2013). Direct Trade Coffee: Prospects and Pitfalls. (Master's Thesis, University of } \\
\text { Calgary, Calgary, Canada). }\end{array}$ \\
\hline A3 & $\begin{array}{l}\text { Birkenberg, A. S. (2019). The potential of certification for climate change mitigation in the agri-food } \\
\text { sector: a case study of carbon neutral certified coffee from Costa Rica (Doctoral Dissertation, } \\
\text { University of Hohenheim, Stuttgart, Germany). }\end{array}$ \\
\hline A4 & $\begin{array}{l}\text { Borrella, I., Mataix, C., \& Carrasco-Gallego, R. (2015). Smallholder farmers in the speciality coffee } \\
\text { industry: opportunities, constraints and the businesses that are making it possible. IDS Bulletin, } \\
46(3), 29-44 \text {. }\end{array}$ \\
\hline A5 & $\begin{array}{l}\text { Bro, A., \& Clay, D. C. (2017). Transforming Burundi's coffee sector through strategic value chain } \\
\text { investments. Journal of Agribusiness in Developing and Emerging Economies 7(3), 218-230. }\end{array}$ \\
\hline A6 & $\begin{array}{l}\text { Clay, D. C., Bro, A. S., Church, R. A., Ortega, D. L., \& Bizoza, A. R. (2018). Farmer incentives and value } \\
\text { chain governance: Critical elements to sustainable growth in Rwanda's coffee sector. Journal of Rural } \\
\text { Studies, } 63,200-213 \text {. }\end{array}$ \\
\hline A7 & $\begin{array}{l}\text { Compigne, I. (2018). High quality coffee value chains for smallholder livelihoods in the Yungas of La } \\
\text { Paz Bolivia (Master's Thesis, Norwegian University of Life Sciences, Ås, Norway). }\end{array}$ \\
\hline A8 & $\begin{array}{l}\text { Cotter, W. M., \& Valentinsson, M. C. (2018). Bivalent class indexing in the sociolinguistics of specialty } \\
\text { coffee talk. Journal of Sociolinguistics, 22(5), 489-515. }\end{array}$ \\
\hline A9 & $\begin{array}{l}\text { Cuellar-Gomez, O. L. (2008). Coffee Produced by Women in Cauca, Colombia: Where has Juanita } \\
\text { Valdez Been? (Master's Thesis, University of Arizona, Tucson, United States). }\end{array}$ \\
\hline A10 & $\begin{array}{l}\text { Dillon, P. J. (2016). Exploring corporate social responsibility: the roles of organizational identity and } \\
\text { social creativity (Doctoral Dissertation, University of Massachusetts, Amherst, United States). }\end{array}$ \\
\hline A11 & $\begin{array}{l}\text { Dohrn, C. A. (2013). A case study of small-scale coffee production: coffee farming as a potential tool } \\
\text { for environmental conservation and community development in rural Minas Gerais, Brazil. } \\
\text { Interdisciplinary Environmental Review, } 14 \text { (1), 1-31. }\end{array}$ \\
\hline
\end{tabular}




\begin{tabular}{|c|c|}
\hline A12 & $\begin{array}{l}\text { nnet, M. L., Jeitschko, T. D., \& Weatherspoon, D. D. (2011). The Impact of E-Auctions in Adjusting } \\
\text { ocurement Strategies for Specialty Coffee. Canadian Journal of Agricultural Economics, 59, 63-86. }\end{array}$ \\
\hline A13 & $\begin{array}{l}\text { ugherty, D. M. (2008). A sense of taste with a sense of place: coffee identities across the United } \\
\text { ates and El Salvador (Master's Thesis, Georgetown University, Washington, United States). }\end{array}$ \\
\hline A14 & $\begin{array}{l}\text { Dowdall, C. M. (2012). Small farmer market knowledge and specialty coffee commodity chains in } \\
\text { Western Highlands Guatemala (Doctoral Dissertation, Florida International University, Miami, } \\
\text { United States). }\end{array}$ \\
\hline A15 & $\begin{array}{l}\text { uursma, L. (2016). Coffee cultivation and tourism: Effects of agritourism on sustainable coffee } \\
\text { oduction in Colombia (Master's Thesis, Utrecht University, Utrecht, Netherlands). }\end{array}$ \\
\hline A16 & $\begin{array}{l}\text { Penker, M. (2020). Analytic framework to determine proximity } \\
\text { logia Ruralis, } 60(2), 458-481 \text {. }\end{array}$ \\
\hline A17 & $\begin{array}{l}\text { m bean to cup and beyond: exploring ethical consumption and } \\
\text { thics, 2(2), 34- } 47 \text {. }\end{array}$ \\
\hline A18 & d inequality: creating value worlds with Third Wave coffee. Socio- \\
\hline A19 & $\begin{array}{l}\text { as de Barrios, L. (2020). Quality versus solidarity: Third Wave coffee } \\
\text { smallholding Maya farmers in Guatemala. The Journal of Peasant } \\
66150.2019 .1694511\end{array}$ \\
\hline A20 & Cup; The Plight of Coffee (Master's Dissertation, University of \\
\hline A21 & $\begin{array}{l}\text { t, A. M. (2019). Coffee Roasters' Sustainable Sourcing Decisions } \\
\text { ustainability, 11(19), } 5437 .\end{array}$ \\
\hline A22 & $\begin{array}{l}\text { he global coffee value chain and production } \\
\text { 8. }\end{array}$ \\
\hline A23 & $\begin{array}{l}\text { fé Sob a Ótica da Construção de Mercados } \\
\text { s, Brazil). }\end{array}$ \\
\hline A24 & $\begin{array}{l}\text { 16). A Terceira Onda do Café em } \\
\text { 27. }\end{array}$ \\
\hline A25 & $\begin{array}{l}\text { Following the supply chain from } \\
\text { rway). }\end{array}$ \\
\hline A26 & $\begin{array}{l}\text { Anunu, C., Bennett, R., \& van Es, } \\
\text { ins: The case of the relationship } \\
\text { 88. }\end{array}$ \\
\hline A27 & $\begin{array}{l}\text { Irup, S. (2016). Coordinating quality practices in Direct Trade coffee. } \\
\text { (186-196. }\end{array}$ \\
\hline A28 & $\begin{array}{l}\text { Holmberg, S. R. (2011). Solving the" Coffee Paradox": Understanding Ethiopia's Coffee Cooperatives } \\
\text { Through Elinor Ostrom's Theory of the Commons (Doctoral Dissertation, University of } \\
\text { Massachusetts, Amherst, United States). }\end{array}$ \\
\hline A29 & $\begin{array}{l}\text { Hotvedt, M. E. (2012). Buy Global, Think Local: Direct Trade Coffee and Community Renaissance in } \\
\text { Olympia, Washington (Senior Thesis, Claremont McKenna College, Claremont, United States). }\end{array}$ \\
\hline A30 & $\begin{array}{l}\text { Hämäläinen, M. (2018). BETTER COFFEE? The Intertwining of Ethics and Quality in the Third-Wave } \\
\text { Coffee Subculture (Master's Thesis, University of Helsinki, Helsinki, Finland). }\end{array}$ \\
\hline A31 & $\begin{array}{l}\text { (2016). Trust, Power, \& Cognitive Proximity: identifying critical factors for how stakeholders } \\
\text { borate for a more sustainable coffee supply chain (Master's Thesis, Utrecht University, } \\
\text { vetherlands). }\end{array}$ \\
\hline A32 & $\begin{array}{l}\text { Knowles, E. C. (2015). Marketing strategies to increase profits from retailing fair trade coffee } \\
\text { (Doctoral Dissertation, Walden University, Minneapolis, United States). }\end{array}$ \\
\hline A33 & $\begin{array}{l}\text { Kolk, A., \& Lenfant, F. (2016). Hybrid business models for peace and reconciliation. Business } \\
\text { Horizons, 59(5), 503-524. }\end{array}$ \\
\hline & 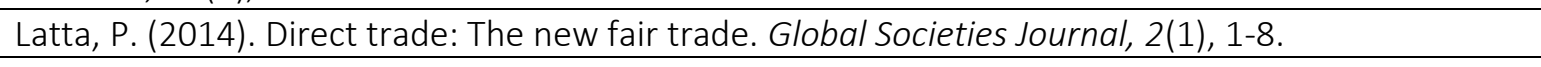 \\
\hline
\end{tabular}




\begin{tabular}{|c|c|}
\hline A35 & $\begin{array}{l}\text { B. A. (2011). Fair trade and development goals in the coffee sector (Master's Dissertation, } \\
\text { I University, Chicago, United States). }\end{array}$ \\
\hline A36 & $\begin{array}{l}\text { eson, M. A. (2013). Burundi in the World of Direct Trade and Specialty Coffee (Master's } \\
\text { sertation, University of Oslo, Oslo, Norway). }\end{array}$ \\
\hline A37 & $\begin{array}{l}\text { 1, Y. (2016). Configuring the Qualification of Good Coffee an Ethnography on the Specialty Coffee } \\
\text { lustry in Milwaukee (Master's Dissertation, University of Wisconsin, Milwaukee, United States). }\end{array}$ \\
\hline A38 & $\begin{array}{l}\text { kas, K. D. (2015). The Supply Chain Of Fair Trade Coffee: Challenges, Opportunities \& The Future } \\
\text { side A Troubled Industry (Master's Dissertation, University of Vermont, Burlington, United States). }\end{array}$ \\
\hline A39 & $\begin{array}{l}\text { MacGregor, F., Ramasar, V., \& Nicholas, K. A. (2017). Problems with Firm-Led Voluntary } \\
\text { Sustainability Schemes: The Case of Direct Trade Coffee. Sustainability, 9(4), } 651 . \\
\text { doi:10.3390/su9040651 }\end{array}$ \\
\hline A40 & $\begin{array}{l}\text { eng-Han, C. (2018). International Master's program of Democracy and Global Transformation } \\
\text { laster's Thesis, University of Helsinki, Helsinki, Finland). }\end{array}$ \\
\hline A41 & $\begin{array}{l}\text { sati, E., Walumbwa, F. O., Lahiri, S., \& Kundu, S. K. (2 } \\
\text { medium enterprises (SMEs): a South-North patter }\end{array}$ \\
\hline A42 & $\begin{array}{l}\text { otsinger, J. H. (2018). Virtuous discourse in the specialty coffee sector: How social responsibility } \\
\text { actices fragment pursuits for a supply chain (Master's Thesis, University of New Mexico, } \\
\text { ouquerque, Mexico). }\end{array}$ \\
\hline A43 & $\begin{array}{l}\text { ר, J., \& Shonk, F. (2014). Chained to development? Livelihoods and global value chains in the } \\
\text {-producing Toraja region of Indonesia. Australian Geographer, 45(3), 269-288. }\end{array}$ \\
\hline A44 & $\begin{array}{l}\text { eing and women } \\
\text { s Santos Region, }\end{array}$ \\
\hline A45 & openhagen Business \\
\hline A46 & $\begin{array}{l}\text { lido, M. (2017). Formulating a strategy for an E-commerce of specialty coffee: Startup company } \\
\text { Netherlands (Master's Dissertation, Haaga-Helia University of Applied Sciences, Helsinki, } \\
\text { lland). }\end{array}$ \\
\hline A47 & a de seus agentes \\
\hline A48 & $\begin{array}{l}\text { ns (2015). The Specialty Questio } \\
\text { elor's Thesis, Wesleyan University }\end{array}$ \\
\hline A49 & senberg, L., Swilling, M., \& Verme \\
\hline A50 & $\begin{array}{l}\text { uiñones-Ruiz, X. F. (2017). Tow } \\
\text { s, 6(2), } 17 .\end{array}$ \\
\hline A51 & $\begin{array}{l}\text { hroeder, S. (2015). When Ethics Are Good for Bus } \\
\text { Direct Trade for Three Speciality Coffee Roaster }\end{array}$ \\
\hline A52 & $\begin{array}{l}\text { ing the tale of the new coffee commodity chain (Master's } \\
\text { erlands). }\end{array}$ \\
\hline A53 & $\begin{array}{l}\text { and, E. (2014). Understanding differentiated coffee-a value chain perspective (Master's } \\
\text { ssertation, University of Nordland, Bod } \varnothing \text {, Norway). }\end{array}$ \\
\hline A54 & $\begin{array}{l}\text { 18). Upgrading for whom? Relationship coffee, } \\
\text { idonesia. World Development, 110, 26-37. }\end{array}$ \\
\hline A55 & $\begin{array}{l}\text { ggt, M. A. B. (2020). Developing stronger association between market value of coffee and } \\
\text { nctional biodiversity. Journal of Environmental Management, } 269,110777 \text {. }\end{array}$ \\
\hline A56 & $\begin{array}{l}\text { ilson, N. L., Wilson, A., \& Whittingham, K. (2013). Helping consumers "know who grows" their } \\
\text { ffee: The case of THRIVE farmers coffee. International Food and Agribusiness Management }\end{array}$ \\
\hline
\end{tabular}


APPENDIX B - List of selected technical materials

\begin{tabular}{|c|c|}
\hline Code & Reference \\
\hline $\mathrm{T} 1$ & $\begin{array}{l}\text { Albers, J. (2015, September 24). How Can Ecotourism Promote Sustainable Coffee Production? } \\
\text { Perfect Daily Grind. Retrieved from https://perfectdailygrind.com/2015/09/how-can- } \\
\text { ecotourism-promote-sustainable-coffee-production/ }\end{array}$ \\
\hline $\mathrm{T} 2$ & $\begin{array}{l}\text { Bocchi, V. (2019, January 03). How Is Green Coffee Bought \& Sold? Perfect Daily Grind. } \\
\text { Retrieved from https://perfectdailygrind.com/2019/01/how-is-green-coffee-bought-sold/ }\end{array}$ \\
\hline T3 & $\begin{array}{l}\text { Bramucci, G., \& Mulholland, S. (2011). More than } 27 \text { cents a day - the Direct Trade (r)evolution. } \\
\text { In: S. F. Parker, \& M. W. Coffee - Philosophy for Everyone (pp. 175-182). West Sussex: Wiley- } \\
\text { Blackwell. }\end{array}$ \\
\hline T4 & $\begin{array}{l}\text { Burgess-Yeo, S. (2019, May 10). Dialing In The Dollars: Tips For Serving a High-Value Coffee. } \\
\text { Perfect Daily Grind. Retrieved from https://perfectdailygrind.com/2019/05/dialing-in-the- } \\
\text { dollars-tips-for-serving-a-high-value-coffee/ }\end{array}$ \\
\hline T5 & $\begin{array}{l}\text { Charles, S. (2020, February 19). How Roasters \& Producers Can Improve Green Bean Sampling. } \\
\text { Perfect Daily Grind. Retrieved from https://perfectdailygrind.com/2020/02/how-roasters- } \\
\text { producers-can-improve-green-bean-sampling/ }\end{array}$ \\
\hline T6 & $\begin{array}{l}\text { Cole, N. L. (2014). Ethical Consumption in the Global Age: Coffee's Promise of a Better World. } \\
\text { In: N. Mathur. Consumer Culture, Modernity, and Identity (pp. 318-344). New Delhi: Sage } \\
\text { Publications. }\end{array}$ \\
\hline T7 & $\begin{array}{l}\text { Davids, K. (2013). The competing languages of coffee - signs, narratives, and symbols of } \\
\text { american specialty coffee. In: R. W. Thurston, J. Morris, \& S. Steiman. Coffee-A comprehensive } \\
\text { guide to the bean, the beverage, and the industry (pp. 296-304). Maryland: Rowman \& } \\
\text { Littlefield. }\end{array}$ \\
\hline T8 & $\begin{array}{l}\text { Daviron, B., \& Ponte, S. (2013). The Coffee Paradox: Global markets, commodity trade and the } \\
\text { elusive promise of development. London: Zed Books. }\end{array}$ \\
\hline T9 & $\begin{array}{l}\text { De Hoog, B. (2017, September 22). Why We Know Less Than We Think About Coffee } \\
\text { Production. Perfect Daily Grind. Retrieved from https://perfectdailygrind.com/2017/09/why- } \\
\text { we-know-less-than-we-think-about-coffee-production/ }\end{array}$ \\
\hline T10 & $\begin{array}{l}\text { Ferguson, M. (2012, February 15). Long-Term Bean Counting: What You Need to Know About } \\
\text { Buying Right. SCA News. Retrieved from https://scanews.coffee/2012/02/15/long-term-bean- } \\
\text { counting-what-you-need-to-know-about-buying-right/ }\end{array}$ \\
\hline T11 & $\begin{array}{l}\text { Germain, S. (2012, February 14). Direct Trade: Going Straight to the Source. SCA News. } \\
\text { Retrieved from https://scanews.coffee/2012/02/14/direct-trade-the-questions-answers/ }\end{array}$ \\
\hline T12 & $\begin{array}{l}\text { Guerra, G. (2018, July 25). How Can Long-Term Relationships Increase Sustainability at Origin? } \\
\text { Perfect Daily Grind. Retrieved from https://perfectdailygrind.com/2018/07/how-can-long- } \\
\text { term-relationships-increase-sustainability-at-origin/ }\end{array}$ \\
\hline T13 & $\begin{array}{l}\text { Guevara, J. (2018, January 02). What Does "Direct Trade" Really Mean? Perfect Daily Grind. } \\
\text { Retrieved from https://perfectdailygrind.com/2018/01/what-does-direct-trade-really-mean/ }\end{array}$ \\
\hline T14 & $\begin{array}{l}\text { Gumm, B. (2019, August 06). How Coffee Roasters Can Use Direct Relationships With } \\
\text { Producers. Perfect Daily Grind. Retrieved from https://perfectdailygrind.com/2019/08/how- } \\
\text { coffee-roasters-can-use-direct-relationships-with-producers/ }\end{array}$ \\
\hline T15 & $\begin{array}{l}\text { Halevy, A. Y. (2011). The infinite emotions of coffee. Los Altos: Macchiatone Communications, } \\
\text { LLC. }\end{array}$ \\
\hline T16 & $\begin{array}{l}\text { Harper, J. (2019, November 28). How Can Roasters Market Sustainable Coffee? Perfect Daily } \\
\text { Grind. Retrieved from https://perfectdailygrind.com/2019/11/how-can-roasters-market- } \\
\text { sustainable-coffee/ }\end{array}$ \\
\hline T17 & $\begin{array}{l}\text { Hartmann, J. (2011). Starbucks and the Third Wave. In: S. F. Parker, \& M. W. Coffee - Philosophy } \\
\text { for Everyone (pp. 154-165). West Sussex: Wiley-Blackwell. }\end{array}$ \\
\hline
\end{tabular}




\begin{tabular}{|c|c|}
\hline T18 & $\begin{array}{l}\text { ernandez, A. M. (2018, November } 21 \text { ). Should Coffee Producers Listen to Roasters' Advice? } \\
\text { rfect Daily Grind. Retrieved from https://perfectdailygrind.com/2018/11/should-coffee- } \\
\text { oducers-listen-to-roasters-advice/ }\end{array}$ \\
\hline T19 & $\begin{array}{l}\text { anniah, J. C. (2020, March 18). The Importance of Growing Consumption in Producing } \\
\text { ountries. Perfect Daily Grind. Retrieved from https://perfectdailygrind.com/2020/03/the- } \\
\text { mportance-of-growing-consumption-in-producing-countries/ }\end{array}$ \\
\hline T20 & $\begin{array}{l}\text { Killbride, D. (2016, September 01). Producer Interview: Direct Trade Is a Two-Way Street. } \\
\text { Perfect Daily Grind. Retrieved from https://perfectdailygrind.com/2016/09/producer- } \\
\text { interview-direct-trade-is-a-two-way-street/ }\end{array}$ \\
\hline T21 & $\begin{array}{l}\text { Kubota, L. (2011, October 16). Friendly Competition: There is No "l" in Coffee. SCA News. } \\
\text { Retrieved from https://scanews.coffee/2011/10/16/friendly-competition-there-is-no-i-in- } \\
\text { coffee/ }\end{array}$ \\
\hline T22 & $\begin{array}{l}\text { Latimore, Z. (2016, October 12). Opinion: Coffee Farming Communities Need More Than Direct } \\
\text { Trade. Perfect Daily Grind. Retrieved from https://perfectdailygrind.com/2016/10/opinion- } \\
\text { coffee-farming-communities-need-more-than-direct-trade/ }\end{array}$ \\
\hline T23 & $\begin{array}{l}\text { Lee, J. (2016, November 14). Under The Microscope: How Do Exporters Work With Coffee } \\
\text { Farmers? Perfect Daily Grind. Retrieved from https://perfectdailygrind.com/2016/11/under- } \\
\text { the-microscope-how-do-exporters-work-with-coffee-farmers/ }\end{array}$ \\
\hline T24 & $\begin{array}{l}\text { Mena, F. A. (2014, May 03). Expanding the Role of the Exporter in the Direct Trade Model. SCA } \\
\text { News. Retrieved from https://scanews.coffee/2014/05/03/expanding-the-role-of-the- } \\
\text { exporter-in-the-direct-trade-model/ }\end{array}$ \\
\hline T25 & $\begin{array}{l}\text { Nadelberg, E. et al. (2017). Trading and Transaction - Market and Finance Dynamics. In: B. } \\
\text { Folmer. The Craft and Science of Coffee (pp. 205-223). London: Academic Press. }\end{array}$ \\
\hline T26 & $\begin{array}{l}\text { Ospina, A. K. M. (2018a, February 15). Micro Roaster? Here's } \\
\text { Know. Perfect Daily Grind. Retrieved from https://perfect } \\
\text { roaster-heres-what-producers-want-you-to-know/ }\end{array}$ \\
\hline T27 & $\begin{array}{l}\text { Ospina, A. K. M. (2018b, May 17). How Can Coffee Auctions Enab } \\
\text { Perfect Daily Grind. Retrieved from https://perfectdailygrind.c } \\
\text { auctions-enable-direct-trade-relationships/ }\end{array}$ \\
\hline T28 & $\begin{array}{l}\text { Parker, S. F. (2011). How good the coffee can be - an interview wi } \\
\text { Lounsbury. In: S. F. Parker, \& M. W. Coffee - Philosophy for Everyone } \\
\text { Sussex: Wiley-Blackwell. }\end{array}$ \\
\hline T29 & $\begin{array}{l}\text { punic, A. (2015, September 14). Everything You Need to Know About Single Origin Coffees. } \\
\text { erfect Daily Grind. Retrieved from https://perfectdailygrind.com/2015/09/everything-you- } \\
\text { eed-to-know-about-single-origin-coffees/ }\end{array}$ \\
\hline T30 & $\begin{array}{l}\text { Quiñones, K. (2017, August 24). How Roasters Can Build Good Relationships With Coffee } \\
\text { Producers. Perfect Daily Grind. Retrieved from https://perfectdailygrind.com/2017/08/how- } \\
\text { roasters-can-build-good-relationships-with-coffee-producers/ }\end{array}$ \\
\hline T31 & $\begin{array}{l}\text { Raad, T. (2017, December 07). Specialty vs Commodity: How Yield, Quality, \& Prices Interact. } \\
\text { Perfect Daily Grind. Retrieved from https://perfectdailygrind.com/2017/12/specialty-vs- } \\
\text { commodity-how-yield-quality-prices-interact/ }\end{array}$ \\
\hline T32 & er, L. F., Giovannucci, D., \& Vieira, L. M. (2017). The \\
\hline T33 & $\begin{array}{l}\text { Scoville-Weaver, A. (2016, September 13). Interview: Is a Direct Trade Collective the Best Model } \\
\text { for Small Farmers? Perfect Daily Grind. Retrieved from } \\
\text { https://perfectdailygrind.com/2016/09/interview-is-a-direct-trade-collective-the-best-model- } \\
\text { for-small-farmers/ }\end{array}$ \\
\hline T34 & $\begin{array}{l}\text { Sherfey, J. (2015, March 29). Case Study: Cultivating Quality in Honduras Through Relationship } \\
\text { Coffee. SCA News. Retrieved from https://scanews.coffee/2015/03/29/case-study-cultivating- }\end{array}$ \\
\hline
\end{tabular}




\begin{tabular}{|l|l|}
\hline T35 & $\begin{array}{l}\text { Squires, E. (2016, September 07). Under the Microscope: What Does a Coffee Importer Do? } \\
\text { Perfect Daily Grind. Retrieved from https://perfectdailygrind.com/2016/09/under-the- } \\
\text { microscope-what-does-a-coffee-importer-do/ }\end{array}$ \\
\hline T36 & $\begin{array}{l}\text { Tark, S. (2019, November 5). Why Knowledge of Coffee Origin Matters. Perfect Daily Grind. } \\
\text { Retrieved from https://perfectdailygrind.com/2019/11/why-knowledge-of-coffee-origin- } \\
\text { matters/ }\end{array}$ \\
\hline T37 & $\begin{array}{l}\text { Tusell, N. (2015, June 30). 5 Things a Micro Roaster Considers When Selecting Coffees. Perfect } \\
\text { Daily Grind. Retrieved from https://perfectdailygrind.com/2015/06/5-things-a-micro-roaster- } \\
\text { considers-when-selecting-coffees/ }\end{array}$ \\
\hline T38 & $\begin{array}{l}\text { Vargas, J. (2019, November 14). A Coffee Producer's Guide to Negotiating. Perfect Daily Grind. } \\
\text { Retrieved from https://perfectdailygrind.com/2019/11/a-coffee-producers-guide-to- } \\
\text { negotiating/ }\end{array}$ \\
\hline T39 & $\begin{array}{l}\text { Watts, G. (2013). Direct Trade in Coffee. In: R. W. Thurston, J. Morris, \& S. Steiman. Coffee-A } \\
\text { comprehensive guide to the bean, the beverage, and the industry (pp. 138-144). Maryland: } \\
\text { Rowman \& Littlefield. }\end{array}$ \\
\hline
\end{tabular}




\section{O COMÉRCIO DIRETO NO MERCADO DE CAFÉS ESPECIAIS: CONTRIBUIÇÕES, LIMITAÇÕES E NOVOS RUMOS DE PESQUISA}

Elisa Reis Guimarães, Antônio Carlos dos Santos, Paulo Henrique Montagnana Vicente Leme, Angélica da Silva Azevedo

Universidade Federal de Lavras - UFLA, Lavras, MG (Brasil)

\section{DETALHES DO ARTIGO}

Histórico do Artigo:

Recebido: 20 de Dezembro de 2019

Aceito: 25 de Junho de 2020

Disponível online: 01 de Agosto de 2020

Sistema de revisão "Double blind review"

Editor Científico

Ilan Avrichir

\section{Palavras-chave:}

Cafés de Relacionamento

Comércio Justo

Sustentabilidade

Estratégia

Café especial

\section{RESUMO}

Objetivo: objetivou-se traçar um panorama da pesquisa e adoção mundiais do Comércio Direto de cafés especiais, destacando suas contribuições, limitações e lacunas teórico-empíricas, fornecendo insights para a realização de estudos futuros. Método: revisão sistemática integrativa de materiais acadêmicos selecionados nas bases Web of Knowledge, Scopus, SciELO, Science Direct e Scholar Google, além de materiais técnicos nos portais da Specialty Coffee Association e o Perfect Daily Grind, os quais foram analisados por meio da técnica de análise de conteúdo qualitativa e categorial de grade aberta.

Principais resultados: Identificaram-se três categorias de contribuições associadas ao Comércio Direto - "Relacionamento e Coordenação", "Origem e Sustentabilidade" e "Qualidade e Diferenciação" e três categorias de suas limitações - "Conceituais e Regulatórias", "Execução e Acompanhamento" e "Acessibilidade e Potencial de Transformação". Apesar de seu grande potencial de contribuir para a promoção da sustentabilidade deste mercado, o Comércio Direto não é solução única para os muitos e complexos desafios da atividade. Portanto, deve ser adaptado às realidades locais e cuidadosamente adotado, de preferência em conjunto com outras iniciativas destinadas a abrir mercados diferentes e atingir públicos distintos.

Relevância/originalidade: esta é a primeira revisão sistemática do assunto, necessária pelo rápido crescimento de estudos no campo, apesar de sua atualidade e apenas recente expansão do debate.

Contribuições teóricas/metodológicas: apresentou-se um novo conceito de Comércio Direto, subdividido em duas vertentes - relacional e transacional - e elaborou-se um framework de sua realização. 


\section{COMERCIO DIRECTO EN EL MERCADO DEL CAFÉ ESPECIAL: CONTRIBUCIONES, LIMITACIONES Y NUEVOS CURSOS DE INVESTIGACIÓN}

Elisa Reis Guimarães, Antônio Carlos dos Santos, Paulo Henrique Montagnana Vicente Leme, Angélica da Silva Azevedo Universidade Federal de Lavras - UFLA, Lavras, MG (Brasil)

\section{HISTORIA DEL ARTÍCULO}

Historia del Artículo:

Recibido: 20 de Diciembre de 2019

Aceptado: 25 de Junio de 2020

Disponible en línea: 01 de Agosto 2020

Double Blind Review System

Editor Científico

Ilan Avrichir

Palabras-clave:

Cafés de relación

Comercio Justo

Sostenibilidad

Estrategia

Café especial

\section{RESUMEN}

Objetivo: delinear la investigación y adopción global del el comercio directo de cafés especiales, destacando sus contribuciones, limitaciones y brechas teóricas y empíricas, proporcionando ideas para futuros estudios.

Método: revisión sistemática integradora de materiales académicos seleccionados de las bases de datos de Web of Knowledge, Scopus, SciELO, Science Direct y Scholar Google, así como materiales técnicos de los portales de Specialty Coffee Association y Perfect Daily Grind, que se analizaron utilizando técnicas de análisis de contenido cualitativo y categórico de categoría abierta.

Resultados principales: Se identificaron tres categorías de contribuciones asociadas con el Comercio Directo: "Relación y coordinación", "Origen y sostenibilidad" y "Calidad y diferenciación" y tres categorías de sus limitaciones: "Conceptual y regulatorio", "Ejecución y monitoreo" y "Accesibilidad y potencial de transformación". A pesar de su gran potencial para contribuir a promover la sostenibilidad de este mercado, Direct Trade no es la única solución a los muchos y complejos desafíos de la actividad, por lo que este modelo de marketing debe adaptarse a realidades locales y cuidadosamente adoptadas, preferiblemente en conjunto con otras iniciativas dirigidas a abrir diferentes mercados y llegar a diferentes audiencias.

Relevancia/originalidad: esta es la primera revisión sistemática del tema, requerida por el rápido crecimiento de los estudios en el campo, a pesar de su oportunidad y la reciente expansión del debate.

Contribuciones teóricas/metodológicas: se presentó un nuevo concepto de Comercio Directo, subdividido en dos aspectos: relacional y transaccional, y se elaboró un marco para su realización.

Cite it like this:

Guimarães, E., dos Santos, A., Leme, P., \& Azevedo, A. (2020). Direct Trade in the Specialty Coffee Market: Contributions, Limitations and New Lines of Research. Internext, 15(3), 34-62. doi:http://dx.doi.org/10.18568/internext.v15i3.588 